\title{
Impact of Po Valley emissions on the highest glacier of the Eastern European Alps
}

\author{
J. Gabrieli ${ }^{1,2}$, L. Carturan ${ }^{3}$, P. Gabrielli ${ }^{4}$, N. Kehrwald ${ }^{1}$, C. Turetta ${ }^{1}$, G. Cozzi ${ }^{1}$, A. Spolaor ${ }^{1}$, R. Dinale ${ }^{5}$, H. Staffler ${ }^{5}$, \\ R. Seppi ${ }^{6}$, G. dalla Fontana ${ }^{3}$, L. Thompson ${ }^{4}$, and C. Barbante ${ }^{1,2}$ \\ ${ }^{1}$ National Research Council, Institute for the Dynamics of Environmental Processes (IDPA-CNR), Dorsoduro 2137, \\ 30123 Venice, Italy \\ ${ }^{2}$ Department of Environmental Sciences, University Ca' Foscari of Venice, Dorsoduro 2137, 30123 Venice, Italy \\ ${ }^{3}$ Department of Land, Environment, Agriculture and Forests, Agripolis, University of Padua, Viale dell'Università 16, \\ 35020 Legnaro, Italy \\ ${ }^{4}$ School of Earth Sciences and Byrd Polar Research Center, The Ohio State University, 108 Scott Hall, 1090 Carmack Road, \\ 43210 Columbus, USA \\ ${ }^{5}$ Autonomous Province of Bolzano - South Tyrol, Department of Fire Control and Civil Protection, viale Drusio 116, \\ 39100 Bolzano, Italy \\ ${ }^{6}$ Earth Science Department, University of Pavia, Via Ferrata 1, 27100 Pavia, Italy
}

Received: 27 November 2010 - Published in Atmos. Chem. Phys. Discuss.: 23 February 2011

Revised: 18 July 2011 - Accepted: 19 July 2011 - Published: 9 August 2011

\begin{abstract}
In June 2009, we conducted the first extensive glaciological survey of Alto dell'Ortles, the uppermost glacier of Mt. Ortles (3905 ma.s.l.), the highest summit of the Eastern European Alps. This section of the Alps is located in a rain shadow and is characterized by the lowest precipitation rate in the entire Alpine arc. Mt. Ortles offers a unique opportunity to test deposition mechanisms of chemical species that until now were studied only in the climatically-different western sector. We analyzed snow samples collected on Alto dell'Ortles from a $4.5 \mathrm{~m}$ snow-pit at $3830 \mathrm{~m}$ a.s.l., and we determined a large suite of trace elements and ionic compounds that comprise the atmospheric deposition over the past two years.

Trace element concentrations measured in snow samples are extremely low with mean concentrations at $\mathrm{pg} \mathrm{g}^{-1}$ levels. Only $\mathrm{Al}$ and $\mathrm{Fe}$ present median values of 1.8 and $3.3 \mathrm{ng} \mathrm{g}^{-1}$, with maximum concentrations of 21 and $25 \mathrm{ng} \mathrm{g}^{-1}$. The median crustal enrichment factor $(\mathrm{EFc})$ values for $\mathrm{Be}, \mathrm{Rb}, \mathrm{Sr}$, $\mathrm{Ba}, \mathrm{U}, \mathrm{Li}, \mathrm{Al}, \mathrm{Ca}, \mathrm{Cr}, \mathrm{Mn}, \mathrm{Fe}, \mathrm{Co}, \mathrm{Ga}$ and $\mathrm{V}$ are lower than 10 suggesting that these elements originated mainly from soil and mineral aerosol. EFc higher than 100 are reported for $\mathrm{Zn} \mathrm{(118),} \mathrm{Ag} \mathrm{(135),} \mathrm{Bi} \mathrm{(185),} \mathrm{Sb} \mathrm{(401)} \mathrm{and} \mathrm{Cd} \mathrm{(514),}$ demonstrating the predominance of non-crustal depositions and suggesting an anthropogenic origin.
\end{abstract}

\section{Correspondence to: J. Gabrieli}

(gabrieli@unive.it)
Our data show that the physical stratigraphy and the chemical signals of several species were well preserved in the uppermost snow of the Alto dell'Ortles glacier. A clear seasonality emerges from the data as the summer snow is more affected by anthropogenic and marine contributions while the winter aerosol flux is dominated by crustal sources. For trace elements, the largest mean $\mathrm{EFc}$ seasonal variations are displayed by $\mathrm{V}$ (with a factor of 3.8), $\mathrm{Sb}$ (3.3), $\mathrm{Cu}$ (3.3), $\mathrm{Pb}$ (2.9), $\mathrm{Bi}$ (2.8), $\mathrm{Cd}$ (2.1), Zn (1.9), Ni (1.8), Ag (1.8), As (1.7) and $\mathrm{Co}$ (1.6).

When trace species ratios in local and Po Valley emissions are compared with those in Alto dell'Ortles snow, the deposition on Mt. Ortles is clearly linked with Po Valley summer emissions. Despite climatic differences between the Eastern and Western Alps, trace element ratios from Alto dell'Ortles are comparable with those obtained from high-altitude glaciers in the Western Alps, suggesting similar sources and transport processes at seasonal time scales in these two distinct areas. In particular, the large changes in trace element concentrations both in the Eastern and Western Alps appear to be more related to the regional vertical structure of the troposphere rather than the synoptic weather patterns. 


\section{Introduction}

Impurities trapped in snow and ice provide insights into past atmospheric composition and environmental variations. In particular, the study of trace elements and ionic compounds contribute to the understanding of changes in past atmospheric circulation and to estimating the relative contribution of different sources. Trace element measurements in ice cores from around the globe are well suited for the determination of natural background concentrations and anthropogenic pollution (Barbante et al., 2011; Hong et al., 2009; Kaspari et al., 2009; Shotyk et al., 2005). During the past few decades, several reconstructions of trace elements and heavy metals in polar ice-cores, especially from Antarctica (Planchon et al., 2003) and Greenland (McConnell et al., 2002), demonstrate consistent anthropogenic pollution in recent snow and ice samples. In contrast to polar regions, the European Alpine glaciers are located near densely populated and industrialized areas and have considerable potential to provide excellent archives for past air pollution. These glaciers may accurately document the environmental impact of European anthropogenic emissions over the previous centuries as well as the efficacy of recently introduced air pollution mitigations (Schwikowski, 2004).

The first trace metal concentrations in Alpine firn and ice samples were obtained from the analysis of a $140 \mathrm{~m}$ snow/ice core drilled on the Dome du Gouter (4304 m a.s.1.), in the Mont Blanc Massif. Van de Velde et al. (1998) determined the seasonal variations of several trace elements $(\mathrm{Pb}, \mathrm{Zn}, \mathrm{Cu}$, $\mathrm{Cd}, \mathrm{Bi}, \mathrm{Mn}$ and Al) from 1960-1968. In addition, two other studies (Van de Velde et al., 1999, 2000) determined the concentrations of $\mathrm{Co}, \mathrm{Cr}, \mathrm{Mo}, \mathrm{Sb}, \mathrm{Au}, \mathrm{Ag}, \mathrm{Pt}, \mathrm{Pd}$ and $\mathrm{Rh}$, in the same ice core covering the last two centuries. Barbante et al. (2001) report the changes in post-World II uranium concentrations. Concentrations of many trace metals $(\mathrm{Cr}, \mathrm{Cd}$, $\mathrm{Zn}, \mathrm{Co}, \mathrm{Ni}, \mathrm{Mo}, \mathrm{Rh}, \mathrm{Pd}, \mathrm{Ag}, \mathrm{Cd}, \mathrm{Sb}, \mathrm{Bi}, \mathrm{Pt}, \mathrm{Au}, \mathrm{U})$ were also determined in a $109 \mathrm{~m}$ ice core drilled in 1982 on Colle Gnifetti, Monte Rosa massif, since 1650 AD (Barbante et al., 2004). Schwikowski et al. (2004) analyzed the same samples for $\mathrm{Pb}$ concentration and isotopes. Surprisingly, little attention has been paid to the investigation of trace metals in fresh snow and seasonal snow-pack from high altitude European Alpine areas and only few reliable data concerning winter snow have been published (Gabrielli et al., 2008; Veysseyre et al., 2001). Moreover no similar studies have ever been conducted on high-altitude glaciers in the Eastern Alps.

In contrast, ionic compounds have been extensively studied in Alpine snow and ice. The historical records of major ions deposition on high-altitude glaciers from the Western Alps were inferred from the following firn and ice cores: Col du Dome near Mont Blanc (Preunkert et al., 1999), Colle Gnifetti (Sigl, 2009; Bolius, 2006) and Grenzgletscher (Eichler et al., 2004) in the Monte Rosa Group; and Fiescherhorngletscher in the Bernese Alps (Eichler et al., 2004). Major ions were also determined in recent snow from the Eastern
Alps: Careser glacier (Novo and Rossi, 1998), Stubai glacier (Kuhn et al., 1998), Sonnblick (Puxbaum and Tscherwenka, $1998)$ and in the snowpack of mid-altitude sites (1500$2650 \mathrm{~m}$ a.s.l.) in the Dolomites (Gabrieli et al., 2008, 2010).

A general prerequisite for the preservation of climatic and environmental information in glaciers is the presence of sufficiently cold firn temperatures and the absence of significant meltwater percolation. Until now, these conditions were expected to occur above $4000 \mathrm{~m}$ a.s.l. and $4300 \mathrm{~m}$ a.s.l. in the northern and southern sectors of the European Alps, respectively (Schwikowski, 2004). Given this possible limitation, only the Mont Blanc region, the Monte Rosa Massif and a few locations in the Bernese Oberland were previously considered as possible drilling sites.

The highest peak of the Eastern Alps is Mt. Ortles (3905 m a.s.1.), located in the Southern Rhaetian Alps, Italy. This area lies at the boundary between the central and southern European climate regions and differs from other well characterized glacial areas of the Western Alps, especially for the amount and seasonality of precipitation (Davis et al., 2003). Brunetti et al. (2006) identifies the Italian Alps as one single homogenous air temperature region (Italian Alpine region, Liguria, and Piedmont), but indicates two precipitation sub-regions: Northwestern Italy and the northern part of Northeastern Italy. Frei and Schär (1998) interpolated valley floor rain gauge datasets and estimated the mean annual precipitation on Ortles as $750-850 \mathrm{~mm} \mathrm{yr}^{-1}$ while Monte Rosa and Mont Blanc receive $1100-1300 \mathrm{~mm} \mathrm{yr}^{-1}$. The region near Mt. Ortles is located in a rain shadow that is often referred to as the inner dry Alpine zone (Frei and Schär, 1998).

While Monte Rosa and Mont Blanc precipitation depict two equinoctial maximums and a winter minimum, the Ortles area of the Eastern Alps is characterized by a single maximum occurring during summer. The percentage of winter precipitation is extraordinarily low in some inner Alpine areas such as the Venosta Valley (Gabrielli et al., 2010). This precipitation pattern can be explained as a possible consequence of the prevailing SW, W and NW cyclonic winds that provide significant precipitation to the southern and northern slope of the Alps and leave the innermost Alpine area in a rain shadow. As a probable consequence of this typical precipitation pattern, the northwestern Alps contained a positive trend during the winter season (1901-1990) while no significant tendencies are reported for the Mt. Ortles region (Schmidli et al. 2002).

To evaluate the potential of Alto dell'Ortles glacier as a glacial archive for paleo-environmental studies, we conducted the first extensive glaciological survey in June 2009. This survey included various glaciological measurements, a ground penetrating radar (GPR) survey, drilling a $10 \mathrm{~m}$ shallow core and sampling a $4.5 \mathrm{~m}$ snow-pit (Gabrielli et al., 2010). Here, we present a new comprehensive dataset of a large suite of trace elements and ionic compounds in snow sampled from the $4.5 \mathrm{~m}$ snow-pit at $3830 \mathrm{~m}$ a.s.l., near the summit of Mt. Ortles. In order to assess any differences 
in the transport and deposition processes of major species and trace metals on the Eastern Alps with respect to the climatically different Western Alps, our chemical data set is discussed in light of the available meteorological and atmospheric circulation data including the boundary layer depth, atmospheric stability and calculated back-trajectories. This paper provides the first data for the seasonal variability of trace species deposition in the Eastern Alps and the impact of human activities on this high altitude environment.

\section{Methods}

\subsection{Study area}

Mt. Ortles $\left(46^{\circ} 30^{\prime} 32^{\prime \prime} \mathrm{N}, 10^{\circ} 32^{\prime} 41^{\prime \prime} \mathrm{E}\right)$ is located in the northern Ortles-Cevedale massif in the Southern Rhaetic Alps (Autonomous Province of Bolzano - South Tyrol, Italy), and is the highest peak in the Eastern European Alps (3905 m a.s.1.) (Fig. 1). This section of the Ortles-Cevedale massif is composed by sedimentary rocks such as stratified dolomites with interblended laminated and slab-shaped black limestone (Desio, 1967). The northwestern flank of Mt. Ortles is covered by the Alto dell'Ortles glacier. The upper part of the glacier has a slope of 8-9 degrees which then flows to steeper bedrock to form two major tongues. The glacier surface area is $1.04 \mathrm{~km}^{2}$ and ranges in elevation from 3905 to $3018 \mathrm{~m}$ a.s.l (Gabrielli et al., 2010).

\subsection{Sampling procedure}

Trace species concentrations in high altitude snow and ice samples are extremely low (ranging from $\mathrm{ng} \mathrm{g}^{-1}$ to sub$\operatorname{pg~}^{-1}$ ). Therefore we collected the samples using the same stringent clean procedures used for collecting snow and firn in polar regions (Planchon et al., 2003). All sampling tools and low-density polyethylene (LDPE) bottles were pre-cleaned with diluted ultra-pure $\mathrm{HNO}_{3}$ (Ultrapure grade, Romil, Cambridge, UK) and then rinsed several times with ultra-pure water (Purelab Ultra Analytic, Elga Lab Water, High Wycombe, UK).

The scientists wore clean-room clothing and polyethylene gloves during the sampling. First, the wall of the snowpit was scraped with a polyethylene bar, removing any exposed area that may have been potentially contaminated during digging. We sampled by plunging LDPE vials perpendicularly into the snow-pit wall with a spatial resolution of $\sim 5 \mathrm{~cm}$ down to a depth of $4.2 \mathrm{~m}$. The collected mass was between $50-90 \mathrm{~g}$, depending on the density of the sampled snow layer. The bottles were capped, packed in double LDPE bags and transported to our laboratories where samples remained frozen until analysis. The snowpack stratigraphy was identified and physical parameters such as temperature, snow density, grain shape and size, hardness indexes (hand test and Swiss Rammesonde method) were measured (Cagnati, 2003). The form of the snow grains and their dimensions

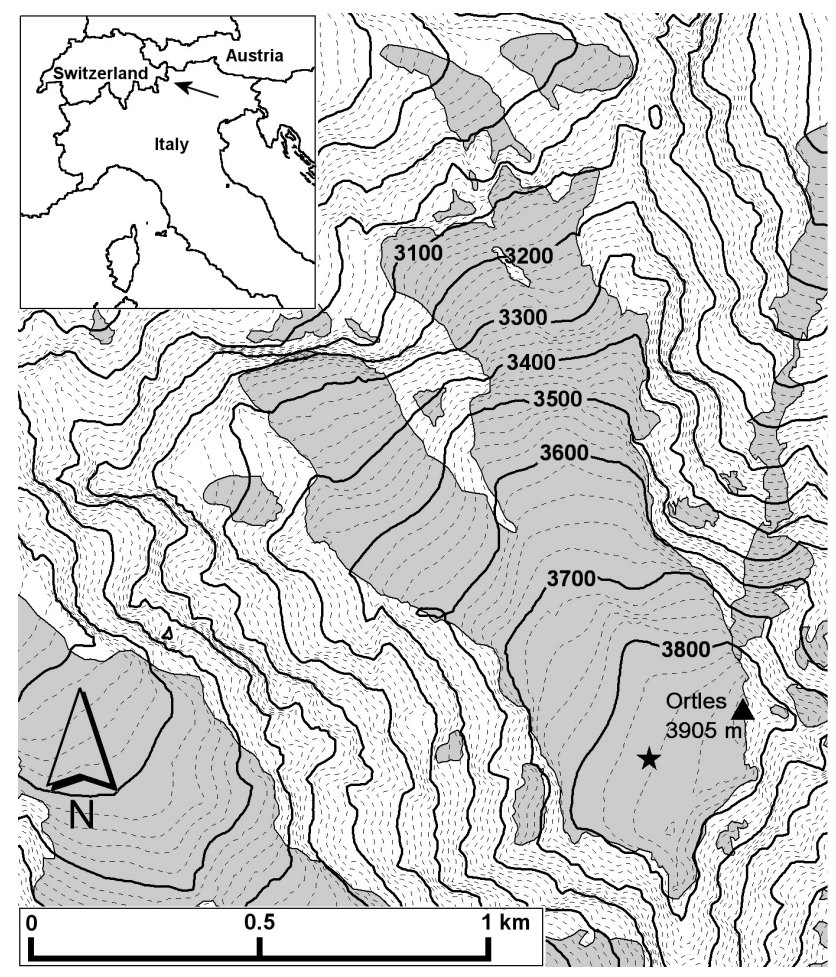

Fig. 1. Map of the Alto dell'Ortles glacier, Southern Rhaetic European Alps, (Autonomous Province of Bolzano - South Tyrol). In grey the glaciarized areas are reported. The star indicates the sampling site while the glaciarized areas are reported in grey (adapted from Gabrielli et al., 2010).

were established according to the International Association of Cryospheric Science classification (Fierz et al., 2009).

\subsection{Sample preparation and chemical analysis}

The samples were melted at room temperature in the LDPE sampling vials in a class 100 laminar flow clean bench. For the trace element analysis, $10 \mathrm{ml}$ aliquots were transferred to $12 \mathrm{ml}$ ultra-clean LDPE vials and acidified with ultra-pure $\mathrm{HNO}_{3}$ to obtain $2 \%$ solutions (v/v). Other $40 \mathrm{ml}$ aliquots were transferred in previously washed polycarbonate $50 \mathrm{ml}$ vials for electrical conductibility, major ions, TOC (Total Organic Carbon) and stable isotope analysis.

Concentrations of $\mathrm{Li}, \mathrm{Be}, \mathrm{Al}, \mathrm{Ti}, \mathrm{V}, \mathrm{Cr}, \mathrm{Mn}, \mathrm{Fe}, \mathrm{Co}, \mathrm{Ni}, \mathrm{Cu}$, $\mathrm{Zn}, \mathrm{Ga}, \mathrm{As}, \mathrm{Rb}, \mathrm{Sr}, \mathrm{Ag}, \mathrm{Cd}, \mathrm{Sb}, \mathrm{Ba}, \mathrm{Tl}, \mathrm{Pb}, \mathrm{Bi}$ and $\mathrm{U}$ were determined by Inductively Coupled Plasma Sector Field Mass Spectrometry (ICP-SFMS; Element2, ThermoFischer, Bremen, Germany) equipped with a desolvation system (APEX IR, Elemental Scientific, Omaha, US). Working conditions and validation tests are described in detail in Gabrieli et al. (2011). Anions $\left(\mathrm{Cl}^{-}, \mathrm{NO}_{2}^{-}, \mathrm{NO}_{3}^{-}, \mathrm{SO}_{4}^{2-}, \mathrm{PO}_{4}^{3-}\right)$ and cations $\left(\mathrm{Ca}^{2+}, \mathrm{Mg}^{2+}, \mathrm{Na}^{+}, \mathrm{K}^{+}, \mathrm{NH}_{4}^{+}\right)$were determined by two ion-chromatographic stations (ICS-1500, Dionex Corporation, Sunnyvale, US). The eluent used was $0.3 \mathrm{mM}$ 
$\mathrm{NaHCO}_{3}$ and $2.7 \mathrm{mM} \mathrm{Na}_{2} \mathrm{CO}_{3}$, eluent flow was conducted at $1.0 \mathrm{ml} \mathrm{min}{ }^{-1}$ on a AG12A $200 \times 40 \mathrm{~mm}$ column (Dionex). For cation analysis, the eluent used was methylsolfonic acid $20 \mathrm{mM}$ at $1.5 \mathrm{ml} \mathrm{min}^{-1}$ rate on a CG12A $200 \times 40 \mathrm{~mm}$ column (Dionex). The injection loop volume was set at $125 \mu \mathrm{l}$. TOC was measured by a catalytic oxidation system coupled with an infrared detector (Perkin Elmer5000, Waltham, MA, USA). Stable isotopes ratios $\left(\delta \mathrm{D}, \delta^{18} \mathrm{O}\right)$ were determined by mass spectrometry (Finnigan Mat Delta+, ThermoScientific, Bremen, Germany).

\section{Results and discussion}

\subsection{Character of the data}

\subsubsection{Trace elements concentrations and fluxes}

The trace elements and ionic compounds show a pronounced variability in concentrations (Table 1). Trace element concentrations measured in snow samples are extremely low with mean concentrations at $\mathrm{pg} \mathrm{g}^{-1}$ level. Only $\mathrm{Al}$ and $\mathrm{Fe}$ present median values of 1.8 and $3.3 \mathrm{ng} \mathrm{g}^{-1}$, with maximum concentrations of 21 and $25 \mathrm{ng} \mathrm{g}^{-1}$, respectively. Ti, $\mathrm{Mn}, \mathrm{Zn}, \mathrm{Sr}$ and $\mathrm{Ba}$ include maximum values higher than 1.0 $\mathrm{ng} \mathrm{g}^{-1}$ while median concentrations are between 0.21 and $0.69 \mathrm{ng} \mathrm{g}^{-1}$. In Table 2, trace element concentrations in the Alto dell'Ortles glacier snow are compared to those from the Colle Gnifetti firn core in the Monte Rosa Group, covering the most recent years of the core (1980-1993) (Gabrieli, 2008). Although the magnitude is comparable, the trace elements concentrations from the Alto dell'Ortles snow pit are generally lower than those determined in the recent Colle Gnifetti firn. For instance, $\mathrm{Pb}$ concentrations are 15 times lower in Alto dell'Ortles while $\mathrm{Ba}, \mathrm{V}, \mathrm{Mn}, \mathrm{Zn}, \mathrm{Fe}$ and $\mathrm{Al}$ are about 3-5 times lower. This variation in concentrations can be explained by differences in regional precipitation where the estimated snow accumulation on the Alto dell'Ortles glacier over the last $3 \mathrm{yr}$ ranged from 550 to $1050 \mathrm{~mm}$ w.e. (Gabrielli et al., 2010) while Colle Gnifetti accumulation ranged from 210 to $450 \mathrm{~mm}$ w.e. (Jenk et al., 2009; Doescher et al., 1995). As the concentrations may be dependent upon accumulation rates, and in spite of possible post-depositional processes (e.g. wind erosion, percolation) that are difficult to quantify, it is likely more representative to calculate deposition fluxes of trace elements (Table 2). The fluxes of $\mathrm{Ba}, \mathrm{Mn}, \mathrm{Fe}$ and $\mathrm{Al}$, which are major constituents of rock and soil, are 50-75\% lower at the Alto dell'Ortles with respect to those at Colle Gnifetti during the last decades, suggesting a lower crustal dust deposition on Mt. Ortles.

In order to evaluate the relative trace element contributions from rock and soil dust versus other sources such as anthropogenic emissions and sea-salt, we calculated the crustal enrichment factors $(\mathrm{EFc}) . \mathrm{EFc}$ is defined as the concentration ratio of a given element to that of a conservative one (in this
Table 1. Main statistics of the species determined in the snow pit on the glacier Alto dell'Ortles. The concentrations of the trace elements are expressed in $\mathrm{pg} \mathrm{g}^{-1}$ while the ionic compounds in $n g g^{-1}$.

\begin{tabular}{|c|c|c|c|c|c|c|}
\hline & Mean & SD & Median & Min & Max & $\begin{array}{r}\text { Max/ } \\
\text { Min }\end{array}$ \\
\hline $\mathrm{Li}$ & 19 & 13 & 15 & 4.9 & 74 & 15 \\
\hline $\mathrm{Be}$ & 1.8 & 1.6 & 1.1 & 0.47 & 9.3 & 20 \\
\hline $\mathrm{Al}$ & 3440 & 4290 & 1785 & 65 & $2.1 \mathrm{E}^{4}$ & 321 \\
\hline $\mathrm{Ti}$ & 450 & 240 & 440 & 11 & 1120 & 105 \\
\hline V & 140 & 180 & 77 & 7.5 & 790 & 105 \\
\hline $\mathrm{Cr}$ & 45 & 99 & 25 & 3.1 & 86 & 28 \\
\hline $\mathrm{Mn}$ & 825 & 1060 & 495 & 19 & 6850 & 356 \\
\hline $\mathrm{Fe}$ & 5340 & 5810 & 3290 & 95 & $2.5 \mathrm{E}^{4}$ & 257 \\
\hline $\mathrm{Co}$ & 13 & 13 & 9.0 & 1.0 & 81 & 80 \\
\hline $\mathrm{Ni}$ & 190 & 146 & 143 & 74 & 910 & 12 \\
\hline $\mathrm{Cu}$ & 155 & 142 & 122 & 18 & 730 & 41 \\
\hline $\mathrm{Zn}$ & 955 & 790 & 690 & 285 & 5610 & 20 \\
\hline $\mathrm{Ga}$ & 3.2 & 2.8 & 2.3 & 0.43 & 13 & 30 \\
\hline As & 19 & 14 & 15 & 3.7 & 91 & 25 \\
\hline $\mathrm{Rb}$ & 44 & 62 & 25 & 3.6 & 425 & 117 \\
\hline $\mathrm{Sr}$ & 680 & 1260 & 265 & 9.7 & 7300 & 755 \\
\hline $\mathrm{Ag}$ & 1.4 & 1.7 & 0.93 & 0.14 & 11 & 76 \\
\hline $\mathrm{Cd}$ & 6.6 & 5.3 & 5.0 & 1.2 & 28 & 23 \\
\hline $\mathrm{Sb}$ & 16 & 15 & 13 & 0.71 & 70 & 98 \\
\hline $\mathrm{Ba}$ & 380 & 460 & 214 & 8.5 & 2360 & 278 \\
\hline $\mathrm{Tl}$ & 5.3 & 2.9 & 4.7 & 1.6 & 20 & 13 \\
\hline $\mathrm{Pb}$ & 108 & 102 & 74 & 7.5 & 514 & 68 \\
\hline $\mathrm{Bi}$ & 2.1 & 1.8 & 1.7 & 0.18 & 8.0 & 45 \\
\hline $\mathrm{U}$ & 2.0 & 1.6 & 1.5 & 0.12 & 7.5 & 61 \\
\hline $\mathrm{Cl}^{-}$ & 60 & 61 & 42 & 5 & 291 & 58 \\
\hline $\mathrm{NO}_{3}^{-}$ & 377 & 410 & 226 & 58 & 2210 & 38 \\
\hline $\mathrm{SO}_{4}^{2-}$ & 297 & 410 & 150 & 16 & 1920 & 120 \\
\hline $\mathrm{Na}^{+}$ & 44 & 44 & 23 & 5 & 214 & 43 \\
\hline $\mathrm{K}^{+}$ & 19 & 18 & 13 & 1.2 & 99 & 99 \\
\hline $\mathrm{Mg}^{2+}$ & 45 & 37 & 35 & 2.0 & 162 & 81 \\
\hline $\mathrm{Ca}^{2+}$ & 281 & 310 & 199 & 10 & 2040 & 204 \\
\hline $\mathrm{NH}_{4}^{+}$ & 207 & 229 & 133 & 3.4 & 1170 & 390 \\
\hline TOC & 383 & 221 & 306 & 179 & 1630 & 9 \\
\hline
\end{tabular}

work we use Ti) which derives mainly from rock and soil dust, normalized to the same concentration ratio in the upper continental crust (Wedepohl, 1995). For instance, the EFc for $\mathrm{Pb}$ is:

$\mathrm{EFc}_{(\mathrm{Pb})}=([\mathrm{Pb}] /[\mathrm{Ti}])_{\text {snow }} /([\mathrm{Pb}] /[\mathrm{Ti}])_{\text {uppercrust }}$.

The crustal dust is transported to the Alto dell'Ortles glacier from several areas (see Sect. 3.5), and therefore may be characterized by elemental compositions that are significantly different from the upper crustal mean. This mixing leads to a higher uncertainty in the determination of the EFc. For this reason we assume that only calculated $\mathrm{EFc}$ values that are 
Table 2. Average concentration and fluxes of trace elements in snow samples collected in the Glacier Alto dell'Ortles snow pit and in the Colle Gnifetti firn core, Monte Rosa (Gabrieli, 2008).

\begin{tabular}{lrrrr}
\hline & \multicolumn{2}{c}{ Concentration $\left(\mathrm{pg} \mathrm{g}^{-1}\right)$} & \multicolumn{2}{c}{ Flux $\left(\mu \mathrm{g} \mathrm{m}^{-2} \mathrm{yr}^{-1}\right)$} \\
\hline & Mt. Ortles & Colle Gnifetti firn & Mt. Ortles & Colle Gnifetti firn \\
\hline $\mathrm{Cr}$ & $2007-2009$ & $1980-1993^{*}$ & $2007-2009$ & $1980-1993^{*}$ \\
$\mathrm{Cu}$ & 45 & 54 & 36 & 24 \\
$\mathrm{Zn}$ & 155 & 214 & 122 & 96 \\
$\mathrm{Co}$ & 955 & 3410 & 755 & 1535 \\
$\mathrm{Ni}$ & 13 & 38 & 10 & 17 \\
$\mathrm{Cd}$ & 191 & - & 151 & - \\
$\mathrm{Sb}$ & 6.6 & 38 & 5.2 & 17 \\
$\mathrm{Bi}$ & 16 & - & 13 & - \\
$\mathrm{U}$ & 2.1 & 3.6 & 1.7 & 1.6 \\
$\mathrm{~Pb}$ & 2 & 13.6 & 1.6 & 6.1 \\
$\mathrm{Ba}$ & 108 & 1655 & 85 & 745 \\
$\mathrm{~V}$ & 380 & 1680 & 300 & 755 \\
$\mathrm{Mn}$ & 140 & 223 & 111 & 100 \\
$\mathrm{Fe}$ & 823 & 2140 & 650 & 960 \\
$\mathrm{Al}$ & 5340 & 16800 & 4220 & 7560 \\
\hline
\end{tabular}

* Gabrieli (2008)

larger than 10 suggest a pronounced contribution from noncrustal sources. The median EFc values for $\mathrm{Be}, \mathrm{Rb}, \mathrm{Sr}, \mathrm{Ba}$, $\mathrm{U}, \mathrm{Li}, \mathrm{Al}, \mathrm{Ca}, \mathrm{Cr}, \mathrm{Mn}, \mathrm{Fe}, \mathrm{Co}, \mathrm{Ga}$ and $\mathrm{V}$ are lower than 10 suggesting that these elements originated mainly from rock and soil dust. For $\mathrm{Tl}, \mathrm{Pb}, \mathrm{Ni}$, and $\mathrm{Cu}$, median $\mathrm{EFc}$ values are between 10 to 100 , and only a few samples contain an EFc lower than 10. This difference suggests that for these elements the anthropogenic contribution is generally important even if it is not always largely predominant with respect to natural sources. EFc higher than 100 are reported for As (107), Zn (118), Ag (135), Bi (185), Sb (401) and Cd (514), demonstrating the predominance of non-crustal depositions and strongly suggesting an anthropogenic origin.

\subsubsection{Ionic compounds concentrations and fluxes}

The mean concentrations of ionic compounds in snow of Alto dell'Ortles are approximately three orders of magnitude higher than those of the trace elements, with a range in means from $19 \mathrm{ng} \mathrm{g}^{-1}$ for $\mathrm{K}^{+}$to over $377 \mathrm{ng} \mathrm{g}^{-1}$ for $\mathrm{NO}_{3}^{-}$ (Table 1). The mean concentrations of $\mathrm{SO}_{4}^{2-}$ and $\mathrm{NO}_{3}^{-}$, and $\mathrm{NH}_{4}^{+}$are $297 \mathrm{ng} \mathrm{g}^{-1}, 377 \mathrm{ng} \mathrm{g}^{-1}$ and $205 \mathrm{ng} \mathrm{g}^{-1}$, respectively. These compounds are produced by the atmospheric oxidation of their precursor gaseous species, $\mathrm{SO}_{2}, \mathrm{NO}_{\mathrm{x}}$ and $\mathrm{NH}_{3}$, primarily emitted by anthropogenic sources and in particular the combustion of fossil fuels, high-temperature combustions and agriculture. In Table 3, the ionic compounds concentrations are compared with those determined in other Alpine sites.
The measured mean concentrations for $\mathrm{SO}_{4}^{2-}$, (163$\left.677 \mathrm{ng} \mathrm{g}^{-1}\right), \mathrm{NO}_{3}^{-}\left(151-1297 \mathrm{ng} \mathrm{g}^{-1}\right)$ and $\mathrm{NH}_{4}^{+}$(41-259 $\mathrm{ng} \mathrm{g}^{-1}$ ) are within the reported ranges determined in other recent snow and ice samples in the European Alps (Gabrieli et al., 2008, 2010; Novo and Rossi, 1998; Kuhn et al., 1998; Puxbaum and Tscherwenka, 1998). The highest concentrations of ionic compounds are generally observed in snow samples from low-medium altitudes (1000-2500 m a.s.1.) in the Eastern Alps (Dolomites, Sonnblick, and Careser). This can be explained considering that the Dolomites and Careser represent the first geomorphologic barrier that may block the pollutants originating from the heavily populated and industrialized Po Valley (Weiss et al., 1999). In addition, these relatively low mountain areas are also affected by the convective transport of local pollutants from the bottom of the valleys.

The high correlation between $\mathrm{Cl}^{-}$and $\mathrm{Na}^{+}\left(R^{2}=\right.$ $0.90 ;$ d.f. $=78 ; p<0.001)$ and their mean mass ratio $(1.4 \pm 0.2)$ is close to the marine ratio of 1.8 , demonstrating a prevalent marine origin of these two ions. The slight $\mathrm{Na}^{+}$excess could be attributed to a minor contribution from crustal sources such as gypsum, which is present in regional closed-basin lakes. This correlation is in accordance with results from other glaciological records in the Western Alps (Eichler et al., 2000; Schwikowski et al., 1999; Maupetit and Delmas, 1994) but not consistent with data from winter snow collected in the Eastern Alps at low-medium elevation (Gabrielli et al., 2008). In the Eastern Alps a slight $\mathrm{Cl}^{-}$ excess was attributed to a minor anthropogenic $\mathrm{HCl}$ contribution. Using $\mathrm{Cl}^{-}$as the marine reference, we calculated 
Table 3. Mean concentration and fluxes of major ions in snow and ice samples in different Alpine sites: glacier Alto dell'Ortles snow pit (mean accumulation $\sim 800 \mathrm{~mm}$ w.e.), Colle Gnifetti firn/ice core (Monte Rosa; $330 \mathrm{~mm}$ w.e.), Col du Dome firn/ice core (Mont

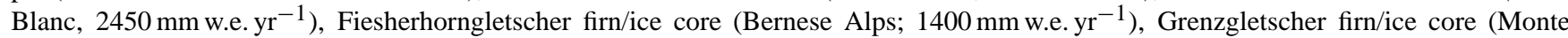

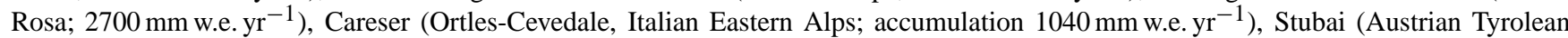
Alps; 1250 mm w.e. $\mathrm{yr}^{-1}$ ), Sonnblick (Austrian Tyrolean Alps), Dolomites (Eastern Italian Alps). The "w" associated with the period indicates that only winter snow was sampled.

\begin{tabular}{|c|c|c|c|c|c|c|c|c|c|c|c|c|}
\hline \multirow{2}{*}{ Site } & \multirow{2}{*}{$\begin{array}{l}\text { Altitude } \\
\text { (m a.s.1.) }\end{array}$} & \multirow{2}{*}{ Period } & \multicolumn{5}{|c|}{ Mean concentration ( $\mathrm{ng} \mathrm{g}^{-1}$ ) } & \multicolumn{5}{|c|}{ Mean fluxes ( $\mathrm{mg} \mathrm{m}^{-2} \mathrm{yr}^{-1}$ ) } \\
\hline & & & $\mathrm{NH}_{4}^{+}$ & $\mathrm{Ca}^{2+}$ & $\mathrm{SO}_{4}^{2-}$ & $\mathrm{NO}_{3}^{-}$ & $\mathrm{Cl}^{-}$ & $\mathrm{NH}_{4}^{+}$ & $\mathrm{Ca}^{2+}$ & $\mathrm{SO}_{4}^{2-}$ & $\mathrm{NO}_{3}^{-}$ & $\mathrm{Cl}^{-}$ \\
\hline Alto dell'Ortles snow-pit & 3850 & $2005-2009$ & 208 & 281 & 297 & 377 & 60 & 166 & 225 & 238 & 302 & 48 \\
\hline ColleGnifetti $^{(\mathrm{a}, \mathrm{b})}$ & 4450 & $1500-1700$ & 38 & 104 & 100 & 87 & 40 & 13 & 34 & 33 & 29 & 13 \\
\hline$(a, b)$ & 4450 & $1950-1980$ & 118 & 159 & 671 & 208 & 47 & 39 & 52 & 221 & 69 & 16 \\
\hline$(a, b)$ & 4450 & $1980-1990$ & 152 & 263 & 677 & 335 & 47 & 50 & 87 & 223 & 111 & 16 \\
\hline$(a, b)$ & 4450 & $1990-2003$ & 211 & 407 & 670 & 447 & 73 & 70 & 134 & 221 & 148 & 24 \\
\hline Col du Dome ${ }^{(c)}$ & 4250 & $1988-1993$ & 97 & 46 & 400 & 280 & 30 & 238 & 113 & 980 & 686 & 74 \\
\hline Fiescherhorngletscher ${ }^{(\mathrm{d})}$ & 3890 & $1945-1983$ & 79 & 100 & 366 & 167 & 52 & 111 & 140 & 512 & 234 & 73 \\
\hline Grenzgletscher ${ }^{(\mathrm{d})}$ & 4200 & $1945-1983$ & 89 & 92 & 384 & 151 & 26 & 240 & 248 & 1037 & 408 & 70 \\
\hline Careser $^{(\mathrm{e})}$ & 3090 & $1994(w)$ & 73 & 24 & 345 & 412 & 260 & 76 & 25 & 359 & 428 & 270 \\
\hline Stubai $^{(\mathrm{f})}$ & 3106 & 1992-1995 & 41 & 42 & 163 & 329 & 39 & 51 & 53 & 204 & 411 & 49 \\
\hline Sonnblick Glacier $^{(\mathrm{g})}$ & 2950 & $1992-1995(w)$ & 259 & 64 & 336 & 763 & 96 & - & - & - & - & - \\
\hline Trentino-Veneto ${ }^{(\mathrm{h})}$ & $1025-3040$ & $1995(w)$ & - & 510 & 530 & 900 & 162 & - & - & - & - & - \\
\hline Dolomites $^{(\mathrm{i})}$ & $1610-2150$ & $2005(w)$ & 172 & 712 & 462 & 1297 & 300 & - & - & - & - & - \\
\hline
\end{tabular}

(a) Bolius, 2006; (b) Sigl, 2009; (c) Preunkert et al., 1999; (d) Eichler et al., 2004; (e) Novo and Rossi, 1998; (f) Kuhn et al., 1998; (g) Puxbaum and Tscherwenka, 1998; (h) Gabrielli et al., 2008; (i) Gabrieli et al., 2010.

the non-sea salt sulfate (NSS) contribution to the total $\mathrm{SO}_{4}^{2-}$ budget as:

$$
\begin{aligned}
{\left[\mathrm{SO}_{4}^{2-}\right]_{\mathrm{NSS}} } & =\left[\mathrm{SO}_{4}^{2-}\right]_{\text {snow }}-\left[\mathrm{Cl}^{-}\right]_{\text {snow }} \\
& \times\left(\left[\mathrm{SO}_{4}^{2-}\right]_{\text {marine }} /\left[\mathrm{Cl}^{-}\right]_{\text {marine }}\right)
\end{aligned}
$$

The marine contribution of $\mathrm{SO}_{4}^{2-}$ is almost negligible, and accounts on average for $6 \%$ of total. The ionic fluxes on Mt. Ortles are similar to those observed at Colle Gnifetti, Careser and Stubai (330-1250 m w.e. $\mathrm{yr}^{-1}$ ) but much lower than at $\mathrm{Col} \mathrm{du}$ Dome, Fiescherhorngletscher and Grenzgletscher, where the accumulation is higher $\left(\sim 1400\right.$ to $\sim 2700 \mathrm{~mm}$ w.e. $\left.\mathrm{yr}^{-1}\right)$. For example, $\mathrm{SO}_{4}^{2-}$ fluxes range from 220 to $360 \mathrm{mg} \mathrm{m}^{-2} \mathrm{yr}^{-1}$ in sites with accumulation lower than $1250 \mathrm{~mm}$ w.e. $\mathrm{yr}^{-1}$ and from 510 to $1040 \mathrm{mg} \mathrm{m}^{-2} \mathrm{yr}^{-1}$ in others where the accumulation is higher than $1400 \mathrm{~mm} w . e . ~_{\mathrm{yr}^{-1}}$ (Table 3). The comparison between deposition on Mt. Ortles and Careser is of particular interest because these two glaciers are only $\sim 15 \mathrm{~km}$ apart from each other and, for this reason, are likely to be comparable. The fluxes of $\mathrm{NO}_{3}^{-}$(300 to $430 \mathrm{mg} \mathrm{m}^{-2} \mathrm{yr}^{-1}$ ) and $\mathrm{SO}_{4}^{2-}$ (240 to $360 \mathrm{mg} \mathrm{m}^{-2} \mathrm{yr}^{-1}$ ) are up to $\sim 50 \%$ greater at Careser while for $\mathrm{Cl}^{-}$are up to 6 times larger ranging between 48 to $270 \mathrm{mg} \mathrm{m}^{-2} \mathrm{yr}^{-1}$. This evidence is consistent with the southern position and lower altitude of Careser and the consequent major impact of pollutants and sea-salt transport from the south.

However, $\mathrm{Ca}^{2+}$ flux is one order of magnitude lower at Careser than on Mt. Ortles. This decrease indicates a significantly lower deposition of carbonate dust on Careser as $\mathrm{Ca}^{2+}$ is the prevailing crustal ion in the snowpack from the mountain areas dominated by carbonate-rich bedrock. The detected fluxes are consistent with the geological characteristics of these two sites. The area near Careser is characterized by metamorphic rocks (mica-schist, gneiss, granites), while the Ortles group is comprised of sedimentary rocks including dolomite and black-banded limestone. This flux difference is consistent with the literature, where measured $\mathrm{Ca}^{2+}$ concentrations in Eastern Alpine winter snow differ between limestone (300-600 $\mathrm{ng} \mathrm{g}^{-1}$ ) and metamorphic (80$220 \mathrm{ng} \mathrm{g}^{-1}$ ) bedrock (Gabrielli et al., 2008).

Very few Total Organic Carbon (TOC) data in snow and ice from high altitude Alpine sites are presented in the literature. In an ice core from Colle Gnifetti, the TOC concentrations increased from 66 to over $614 \mathrm{ng} \mathrm{g}^{-1}$ in the time period between 1890 and 1975 (Lavanchy et al., 1999). TOC concentrations in the Ortles samples range from 180 to $1620 \mathrm{ng} \mathrm{g}^{-1}$, with a median value of $310 \mathrm{ng} \mathrm{g}^{-1}$ and a median TOC flux of $245 \mathrm{mg} \mathrm{m}^{-2} \mathrm{yr}^{-1}$. To the best of our knowledge, these are the first measurements of TOC reported for Alpine recent snow and firn.

\subsection{Stratigraphic and glaciological observations}

Two main snow density transitions were detected at $240 \pm 30 \mathrm{~cm}$ and $360 \pm 30 \mathrm{~cm}$ of depth from twelve snow depth soundings carried out on the upper part of the glacier Alto dell'Ortles (Gabrielli et al., 2010). A comparison of the 
physical and chemical profiles sampled in the snow pit is reported in Fig. 2. The vertical variations in grain shape and size, snow density and hardness index are compared to the vertical profiles of $\delta^{18} \mathrm{O}$ and $\mathrm{NH}_{4}^{+}$. The upper $60 \mathrm{~cm}$ of the snowpack are characterized by medium-size rounded particles, with the presence of partially decomposed precipitation particles. The snow density ranged from 270 to $310 \mathrm{~kg} \mathrm{~m}^{-3}$, and the hardness index is approximately $250 \mathrm{~N}$. These features are consistent with recently deposited dry snow subjected to destructive metamorphic processes. A visible weak dust horizon above a melt-freeze crust was recorded at $60 \mathrm{~cm}$. This layer represents the first clear stratigraphic discontinuity that differentiates the recent 2009 spring snow from the 2008/2009 winter snow. From 60 to $270 \mathrm{~cm}$, the density increased from $300 \mathrm{~kg} \mathrm{~m}^{-3}$ to $400-440 \mathrm{~kg} \mathrm{~m}^{-3}$, and the hardness to from $250 \mathrm{~N}$ to $1000-1500 \mathrm{~N}$. In the layers between 60 to $90 \mathrm{~cm}$, medium size rounded particles $(0.8 \mathrm{~mm})$, faceted rounded particles and solid faceted particles were recovered, indicating kinetic growth processes triggered by temperature gradients. From 90 to $140 \mathrm{~cm}$, a succession of small/medium size $(0.2-1.0 \mathrm{~mm})$ rounded particles layers and thin ice lenses formations $(<10 \mathrm{~mm})$ were visible. Considering that no evidence of winter melting was found, the origin of these $\mathrm{mm}$ scale ice lenses is probably due to wind activity, which is particularly intense on the Alto dell' Ortles glacier during winter. Such thin glaze layers could be also generated during the cold season under strong radiative conditions. Surface layers may melt due to radiation absorption during the day and refreeze due to radiative cooling overnight (sun crusts or firnspiegel) (Ozeki and Akitaya, 1998).

The dust layer at $130 \mathrm{~cm}$ is probably due to a weak Saharan deposition occurring on the 1 and 2 of April 2009. This deposition can be inferred by considering the back-trajectories from Alto dell'Ortles glacier (see Sect. 3.5) and the Saharan event recorded at the Jungfraujoch (Collaud Coen et al., 2004) high alpine research station (3580 m a.s.l.; $46^{\circ} 33^{\prime} \mathrm{N}$, 07 59' E; (Collaud Coen, personal communication, 2010). From 140 to $270 \mathrm{~cm}$, the snow layers were characterized by large rounding-faceted crystals $(1.5-3.0 \mathrm{~mm})$, which are indicative of growth regime transition forms typical of the cold and dry snowpack.

The second strong stratigraphic discontinuity is constituted by the thick ice lens (about $5 \mathrm{~cm}$ ) at $280 \mathrm{~cm}$. Below this discontinuity, all of the crystals that are characteristic of a dry-snowpack disappear and melt forms were observed. The density and the hardness index progressively increased up to $450-500 \mathrm{~kg} \mathrm{~m}^{-3}$ and $2000-2500 \mathrm{~N}$, respectively. The grain shape was dominated by melt forms and, in particular, by large rounded polycrystals $(3.0-3.5 \mathrm{~mm})$ which are generally produced by sequential melt-freeze cycles in low water content conditions such as a pendular regime. Since the particle size of the polycrystals increases as a function of the number of melt-freeze cycles, these layers can be formed only during the summer ablation period at the high elevation of the Alto dell'Ortles glacier. The discontinuity at $275 \mathrm{~cm}$ likely represents the transition between the 2009 and the 2008 firn. Solid faceted particles were found above a thick melt-freeze crust at $60-65 \mathrm{~cm}$ and above the thick ice lens at $280 \mathrm{~cm}$. This kinetic-growth form appears when the rounded particles are subjected to a large increasing vertical temperature gradient in the snow. This suggests that ice and melt-freeze layers act as an effective physical barrier, able to influence the small-scale thermal regime and, perhaps, the meltwater percolation and wet/dry migration processes of both particulate and soluble trace species trapped in the snow. At $395 \mathrm{~cm}$ we observed a dust layer in correspondence with a thick ice lens $(2.0 \mathrm{~cm})$ while the layers from 395 to $450 \mathrm{~cm}$ (the base of the snow-pit) were characterized by large rounded polycrystals. This thick ice lens and associated dust layer could indicate the transition between the 2007/2008 firn but, since no other information could be inferred from the stratigraphy, this is instead corroborated by additional chemical evidence (e.g. high $\mathrm{Cu}$ and $\mathrm{Cd}$ concentrations, see below).

The $\delta^{18} \mathrm{O}$ profile which can be used as proxy of air temperature during precipitation confirms the seasonal reconstruction inferred from the snow-pit stratigraphy, showing higher values during warm periods (between 0-60 and 260$345 \mathrm{~cm}$ ) and lower during cold periods (between 60-260 and $345-400 \mathrm{~cm}$ ). We also verify a correspondence between the highest $\delta^{18} \mathrm{O}$ values and peaks in $\mathrm{NH}_{4}^{+}$, which is an anthropogenic component that is mostly deposited in the summer (Gabrielli et al., 2010). The chemical signature of the 2008/2007 snow transition appears less evident, and may be due to the smoothing effect of meltwater percolation during the 2007 and 2008 summers. A visible dust layer and a corresponding slight increase in $\mathrm{NH}_{4}^{+}$were observed at $395 \mathrm{~cm}$, perhaps suggesting the presence of the 2007 summer layer below $390-400 \mathrm{~cm}$. The seasonal $\delta^{18} \mathrm{O}$ pattern is complicated and variations may be more due to water percolation through the layers than the advection history of the wet air masses that deliver precipitation. In summary, the results of the snow-soundings and the physical and chemical stratigraphic observations indicate that the transitions between the $2009 / 2008$ and the 2008/2007 snow were at about 280 and $385 \mathrm{~cm}$, respectively.

\subsection{Principal Component Analysis (PCA)}

A PCA has been applied to the entire dataset, of 82 snow samples where each sample was analyzed for 22 trace elements, 8 major ions, $\delta^{18} \mathrm{O}$ and TOC to evaluate the aggregation between variables in light of different trace species provenance and sources. As this study only covers two years, the discussion of the PCA should be considered preliminary and not conclusive. The PCA highlights the seasonality and the different trace species sources during the period covered by our investigation. The data distribution for most variables is asymmetric rather than normal, and so a log-normal distribution represents a better fitting. For this reason, we have run the PCA by using the logarithm of the concentrations. 


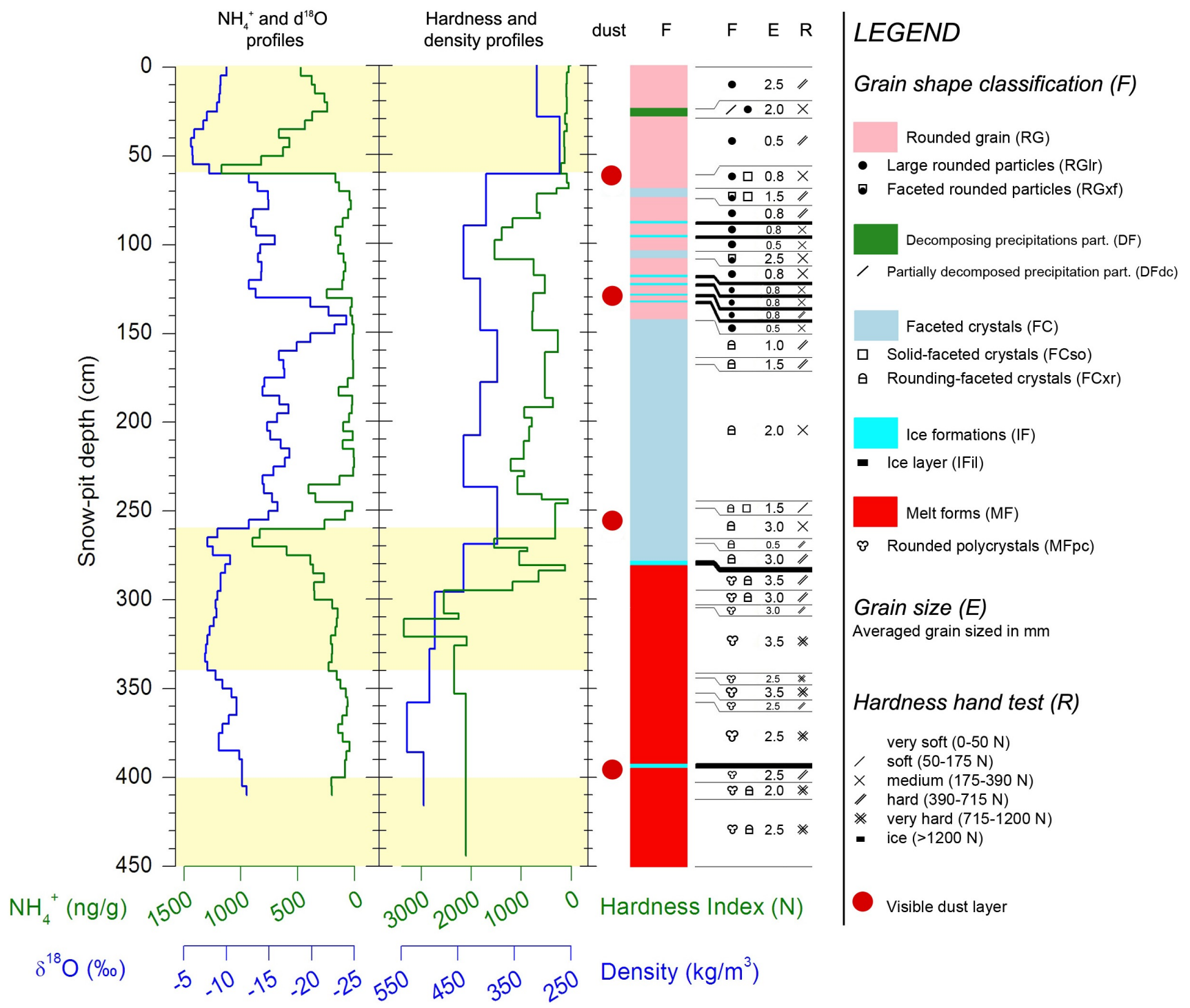

Fig. 2. Stratigraphic observations (grain shape and size), density, hardness index, $\delta^{18} \mathrm{O}$ and $\mathrm{NH}_{4}^{+}$profiles inferred from the snow pit dug on the Alto dell'Ortles glacier. The grain shape has been classified in accordance with the International Classification for Seasonal Snow on the Ground (Fierz et al., 2009); in brackets the synthetic crystal shape code is reported.

Figure 3 (panel a) shows the biplot graph, which represents both the variables and the cases distribution. The first two principal components account for more than $73 \%$ of the total variance in the dataset.

The PC1 explains the main features of the data set and accounts for $63 \%$ of the total variance, with comparable negative loadings for all the variables except TOC and $\delta^{18} \mathrm{O}$. This indicates a quite homogeneous chemical matrix. PC1 discriminates the samples on the base of the aerosol and trace species content. In particular, samples characterized by high concentrations values (warm periods) show very negative loadings (PC1 sectors A, B in Fig. 3, panel a) while diluted samples (cold periods) show positive loadings (PC1 sectors E, F, G in Fig. 3, panel c). This behavior is thus clearly linked with the seasonality as snow deposited during warm periods is characterized by higher concentrations of trace elements and ionic compounds with respect to the cold seasons. Samples characterized by smaller loadings on PC1 show intermediate concentration levels of trace species (PC1 sectors D, E in Fig. 3). These snow layers could have formed in intermediate atmospheric conditions, such as during spring and autumn, or from the mixing of different layers due to post-depositional processes including wind redistribution and/or percolation. The small loadings on PC1 for samples deeper than $300 \mathrm{~cm}$ (Fig. 3, panel b), may be due to percolation of melting water. Despite the large number of samples not clearly discriminated by PC1, by taking into account the samples with important negative and positive 
a)

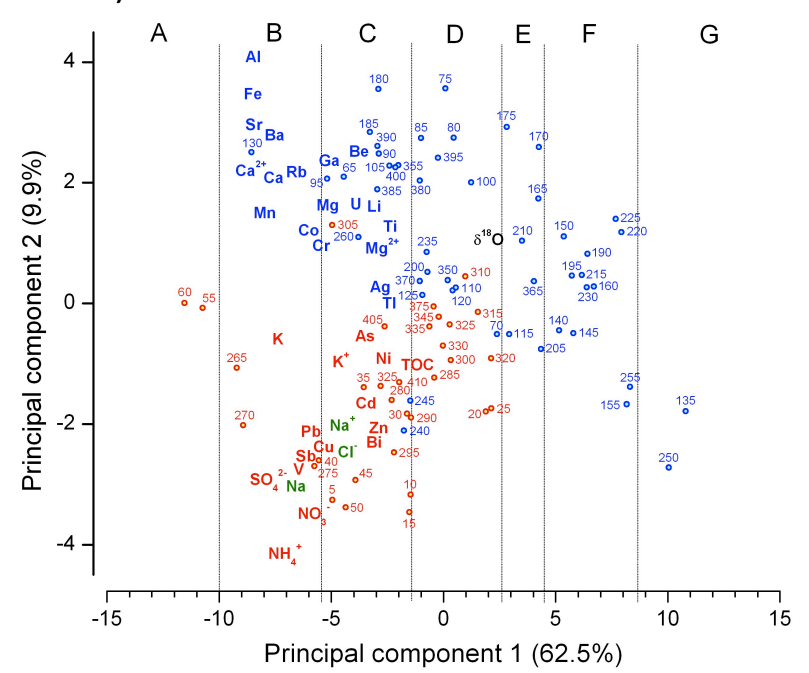

b)

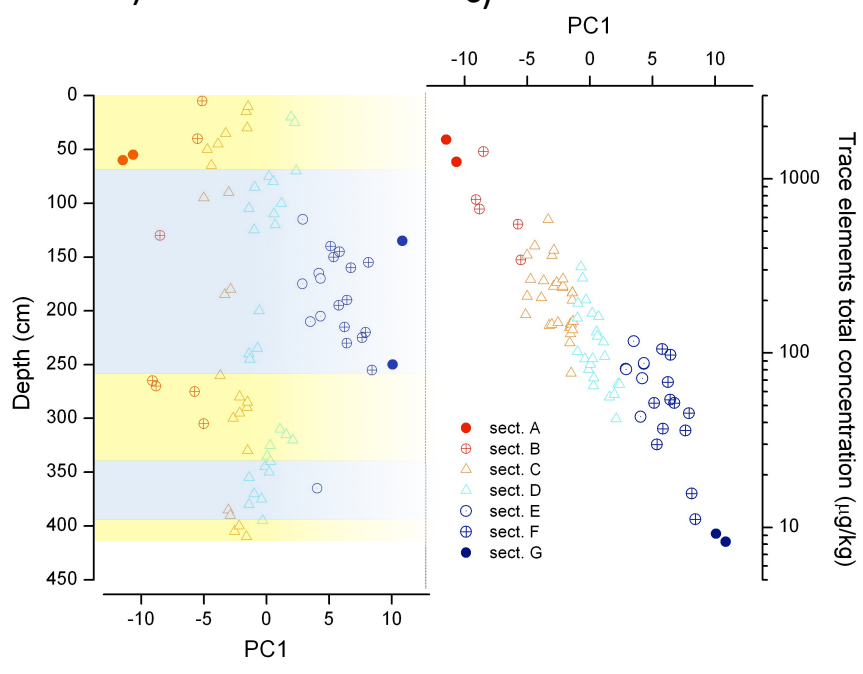

Fig. 3. Principal Component Analysis (PCA) biplot (panel (a)) of all the chemical variables (variable name) and cases (points indicating the depth, in $\mathrm{cm}$, of the corresponding sample) on the first two principal components which explain $62.5 \%$ and $9.9 \%$ of the total variance, respectively. The red-written cases correspond to the samples from warm periods while the black those from cold periods, as inferred from the stratigraphic observations. In panel (b), we show the seasonal distribution (red and blue bands are warm and cold periods, respectively) as reconstructed from the depth profiles (in Fig. 2) of negative and positive PC1 loadings (sectors A, B and E, F, G, respectively). In panel (c), we show the relation between PC1 and the trace element concentration.

loading (sectors A, B and E, F, G on Fig. 3, respectively), we obtain a good seasonal subdivision which is consistent with the stratigraphic observations and the chemical profiles (Fig. 3, panel b).

The second PCA component (PC2) accounts for $10 \%$ of the total variance and has positive loadings for $\mathrm{Mg}^{2+}, \mathrm{Ca}^{2+}$, $\mathrm{Li}, \mathrm{Rb}, \mathrm{Sr}, \mathrm{Ba}, \mathrm{Al}, \mathrm{Ti}, \mathrm{Fe}, \mathrm{Ga}, \mathrm{Mn}, \mathrm{Co}, \mathrm{Cr}, \mathrm{U}, \delta^{18} \mathrm{O}$ and negative loadings for TOC, $\mathrm{NO}_{3}^{-}, \mathrm{SO}_{4}^{2-}, \mathrm{Cl}^{-}, \mathrm{Na}^{+}, \mathrm{NH}_{4}^{+}$, $\mathrm{K}^{+}, \mathrm{As}, \mathrm{Cd}, \mathrm{Cr}, \mathrm{Sb}, \mathrm{Pb}, \mathrm{Bi}, \mathrm{V}, \mathrm{Ni}, \mathrm{Cu}, \mathrm{Zn}$. We interpret PC2 as the component that separates crustal elements from the anthropogenic and marine variables. $\mathrm{Ag}, \mathrm{Tl}$ and $\mathrm{K}$ are not discriminated by PC2 indicating that the sources for these elements may be mixed. In particular, the $\mathrm{K}^{+}$depositions may not only be linked to marine sources but may also be influenced by terrestrial emissions such as biomass burning (Simoneit, 2002).

Despite having different sources, the concentrations of $\mathrm{Cl}^{-}$and $\mathrm{Na}^{+}$the two major proxies of sea-salt, and anthropogenic species are well correlated indicating a similar origin area or transport pathway. This correlation is in contrast with results from an ice-core from the Grenzgletscher glacier (Eichler et al., 2004), where sea-salt related species correlated with crustal dust elements. We suggest that the origin of the sea-salt aerosol deposited on the Eastern Alps is either the Adriatic Sea or it is injected into the air masses during the transport over the Po Valley, whereas in Western Alps the sea-salt aerosol mainly arrives from the southwest.

\subsection{Seasonality of the chemical variables}

Profiles of selected ionic compounds and trace elements are reported in Fig. 4a and b. The $\delta^{18} \mathrm{O}$ record shows a well defined seasonal pattern, with maximum values of up to $-5.8 \%$ o (summer) and minimum values of $-24.1 \%$ (winter), which are typical values for Alpine precipitation at high altitude sites (Schotterer et al., 1997). The anthropogenic ions $\left(\mathrm{NO}_{3}^{-}, \mathrm{NH}_{4}^{+}, \mathrm{SO}_{4}^{2-}\right)$ show a pronounced seasonal pattern with low winter concentrations which increase in spring and peak in summer. $\mathrm{NO}_{3}^{-}$and $\mathrm{NH}_{4}^{+}$show the most pronounced seasonality with summer to winter mean concentrations ratios of 4.2 and 5.3, respectively. For $\mathrm{SO}_{4}^{2-}$, the summer to winter ratio is 3.6 while the sea salt contribution to $\mathrm{SO}_{4}^{2-}$ does not show any evident seasonal variation but always accounts for $10-20 \%$ of the total.

The seasonal variations of $\mathrm{K}^{+}, \mathrm{Mg}^{2+}$ and $\mathrm{Ca}^{2+}$ are less pronounced, demonstrating a quite constant deposition of crustal elements and, therefore, a minor impact of discontinuous inputs such as Saharan depositions. Concentrations of the marine species $\mathrm{Cl}^{-}$and $\mathrm{Na}^{+}$follow a seasonal pattern comparable to those of $\mathrm{NH}_{4}^{+}$and other anthropogenic species, except for a few large isolated peaks in winter. The $\mathrm{Cl}^{-} / \mathrm{Na}^{+}$ratio fluctuates around the mean value of 1.4 , close to the average sea salt value of 1.8 , except in the snow pit section from 320 to $340 \mathrm{~cm}$ of depth, where the mean ranges between 2.4 and 3.0. According to the stratigraphy (Sect. 3.2), this layer is characterized by large rounded polycrystals $(3.5 \mathrm{~mm})$ produced as a consequence of subsequent 

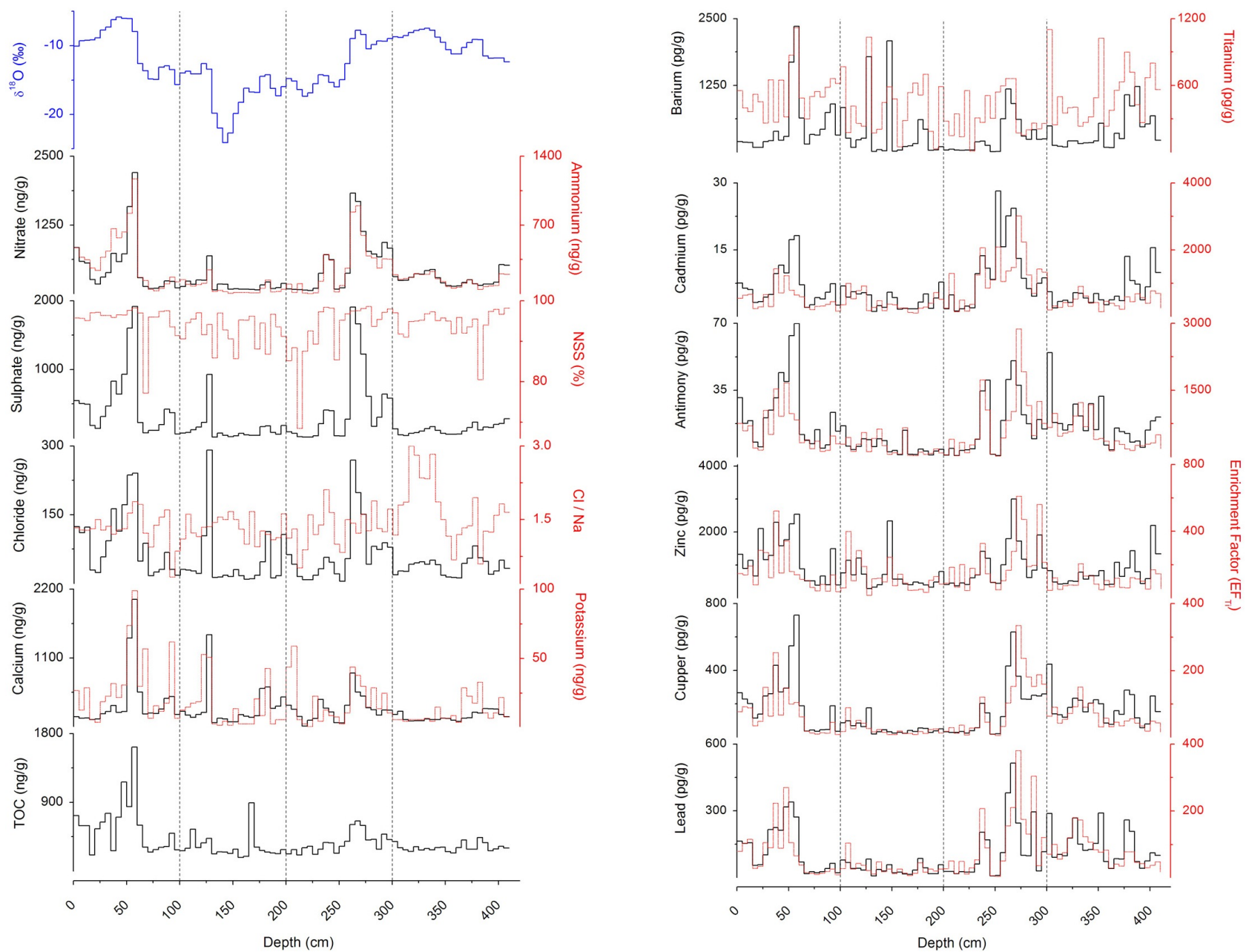

Fig. 4. Depth profiles of $\delta^{18} \mathrm{O}$, major ions concentrations, TOC (a) and of some selected trace elements, and relative enrichment factors (b) in snow samples from the $4.2 \mathrm{~m}$ snow pit on the Alto dell'Ortles glacier.

melt-freeze cycles. The ionic compounds are leached from snow during melt post-depositional process with different efficiencies on the base of the atomic characteristics of the ions and their interaction with the ice crystal lattice. For instance, the elution sequence derived both from laboratory and field experiments demonstrate that $\mathrm{Cl}^{-}$is well preserved while $\mathrm{SO}_{4}^{2-}$ and $\mathrm{Na}^{+}$are strongly affected by meltwater (Eichler et al., 2001). The TOC profile records the highest concentrations from the surface to a depth $65 \mathrm{~cm}$, corresponding to the beginning of the 2009 warm season, while displaying few seasonal variations in the deeper sections of the snow pit. This behavior suggests a more efficient leaching by meltwater percolation for TOC than for $\mathrm{NH}_{4}^{+}$and other anthropogenic compounds.

The $\mathrm{EFc}$ profiles of $\mathrm{Cd}, \mathrm{Sb}, \mathrm{Zn}, \mathrm{Cu}$ and $\mathrm{Pb}$ correlate with each other and their respective concentrations peak in tandem (Fig. 4b). The largest mean EFc seasonal variations for trace elements are displayed by $\mathrm{V}$ (by a factor of 3.8), $\mathrm{Sb}$ (3.3), Cu (3.3), Pb (2.9), Bi (2.8), Cd (2.1), Zn (1.9), Ni
(1.8), Ag (1.8), As (1.7) and Co (1.6). For elements which are most likely anthropogenic, $\mathrm{EFc}$ values increase during summer periods by factors of $1.3(\mathrm{Tl})$ to $3.8(\mathrm{Cu})$ but, even during the winter season, their values remain largely higher than 10 , indicating a predominant anthropogenic origin. As reported for the terrigenous ions $\mathrm{K}^{+}, \mathrm{Mg}^{2+}$ and $\mathrm{Ca}^{2+}$ the crustal trace elements also demonstrate limited $\mathrm{EFc}$ seasonal variations, ranging from $1.0(\mathrm{Ti}, \mathrm{Be}, \mathrm{Li}, \mathrm{Al}, \mathrm{Sr})$ to $1.4(\mathrm{Ba}$, $\mathrm{Rb}, \mathrm{U}$ ). We conclude that despite considerable melting during summer (Gabrielli et al., 2010), the strong seasonal variability as inferred from the snow pit chemical and isotopic profiles suggests only a limited influence of ablation and water percolation on the chemical content of the surface snow layers.

\subsection{Anthropogenic trace element sources}

In Table 4 we summarized selected ratios of trace species $\left(\mathrm{NO}_{\mathrm{x}}, \mathrm{SO}_{\mathrm{x}}, \mathrm{NH}_{4}^{+}\right)$and elements $(\mathrm{Pb}, \mathrm{Zn}, \mathrm{Cd}, \mathrm{Cr}, \mathrm{Ni}, \mathrm{Cu}$, 
Table 4. Trace species ratios for estimated local and Po Valley emissions (2000 AD), Alto dell'Ortles snow and Colle Gnifetti firn (1980 to 1993 AD).

\begin{tabular}{lrrrrrrrr}
\hline & \multicolumn{3}{c}{ Emissions } & & \multicolumn{3}{c}{ Alto dell'Ortles snow pit } & \\
\cline { 2 - 3 } & Po Valley & local & & median & warm & cold & $\begin{array}{r}\text { CG firn } \\
1980-1993\end{array}$ \\
\hline $\mathrm{NO}_{3}^{-} / \mathrm{NH}_{4}^{+}$ & 1.7 & 1.4 & & 1.7 & 2.0 & 2.5 & 2.1 \\
$\mathrm{SO}_{4}^{2-} / \mathrm{Cd}\left(^{*}\right)$ & 27 & 5.9 & & 30 & 39 & 21 & 18 \\
$\mathrm{SO}_{4}^{2-} / \mathrm{Cr}\left(^{*}\right)$ & 5.9 & 1.4 & & 5.9 & 11 & 4.7 & 12 \\
$\mathrm{SO}_{4}^{2-} / \mathrm{Ni}\left(^{*}\right)$ & 1.6 & 0.5 & & 1.1 & 1.5 & 0.7 & - \\
$\mathrm{Pb} / \mathrm{Cd}$ & 32 & 45 & & 15 & 21 & 10 & 44 \\
$\mathrm{~Pb} / \mathrm{Cr}$ & 5.1 & 9.8 & & 2.9 & 5.6 & 2.3 & 31 \\
$\mathrm{~Pb} / \mathrm{Zn}$ & 0.21 & 0.10 & & 0.13 & 0.18 & 0.11 & 0.49 \\
$\mathrm{~Pb} / \mathrm{As}$ & 5.4 & 40 & & 5.1 & 8.2 & 3.1 & - \\
$\mathrm{Cr} / \mathrm{Cd}$ & 6.3 & 2.5 & & 5.1 & 4.7 & 4.5 & 1.4 \\
$\mathrm{Zn} / \mathrm{Cr}$ & 32 & 49 & & 27 & 37 & 29 & - \\
$\mathrm{Zn} / \mathrm{Cu}$ & 8.6 & 35 & & 5.7 & 4.4 & 5.7 & 16 \\
$\mathrm{Zn} / \mathrm{SO}{ }_{4}^{2-}\left(^{\#}\right)$ & 5.1 & 33 & & 4.8 & 3.6 & 4.8 & 5.1 \\
\hline
\end{tabular}

(*) divided by 1000; $(\#)$ multiplied by 1000.

As) determined in emissions from the Po Valley and local areas (in a radius of $\sim 50 \mathrm{~km}$ or less from Mt. Ortles). The emissions are inferred from the national emission inventories created by applying the CORINAIR (CORe INventory AIR emissions) method developed by the European Monitoring and Evaluation Program (EMEP; the Italian data are available at: http://www.sinanet.isprambiente.it/ it/inventaria/disaggregazione_prov2005 at provincial scales). These emissions are compared with the same ratios obtained in Alto dell'Ortles snow/firn layers (median data) and in the Colle Gnifetti firn core (1980-1993) (Gabrieli, 2008). Trace species ratios in snow layers formed during warm periods correlate well with the emission ratios of the Po Valley $\left(R^{2}=0.83, p<0.001\right)$, while the influence of local emissions sources appears to be minor. This is an important new result that suggests the predominance of the regional over the local pollution of trace metals and species at the highest elevations of the Eastern European Alps during summer. The trace species ratios in snow layers formed during cold periods correlate well with the corresponding Po Valley emissions $\left(R^{2}=0.56, p=0.024\right)$ while cold period ratios in Ortles snow differ significantly from local sources $\left(R^{2}=0.21\right.$, $p=0.23)$. The lower correlation coefficients during cold periods indicate a stronger influence of long-range transport. The different summer and winter sources are consistent with the back-trajectories and meteorological data (see below).

The area around Mt. Ortles is mainly rural and mountainous, with a low population density and low levels of manufacturing production. The principal economic activities are linked with tourism, agriculture, and farming, all of which are often conducted as family business. Quantitatively, the local source contributions from the southern and western quadrants (in a radius $<50 \mathrm{~km}$ ) to the total trace species emissions of the Po Valley and surroundings ranges from $1.7 \%(\mathrm{As})$ to $7.1 \%(\mathrm{Zn})$ and $7.4 \%(\mathrm{Ni})$. The ratios between the Po Valley and the local emissions, normalized for the surface area, decrease in this order: As (31), $\mathrm{SO}_{\mathrm{x}}(20), \mathrm{Cr}(13)$, $\mathrm{Zn}(9), \mathrm{Cd}(5), \mathrm{Cu}, \mathrm{NO}_{\mathrm{x}}$ and $\mathrm{NH}_{3}$ (4), $\mathrm{Ni}$ (2).

Ratios of trace species and elements from Alto dell'Ortles and Colle Gnifetti are comparable, indicating a general link between the Po Valley emissions and deposition over highaltitude Alpine glaciers. However, this is different for the $\mathrm{Cr} / \mathrm{Cd}, \mathrm{Zn} / \mathrm{Cu}$ and $\mathrm{Pb} / \mathrm{M}$ ratios. The differences in $\mathrm{Pb}$ ratios are likely due to the higher $\mathrm{Pb}$ emissions in the period 1980-1993 than during recent years. This change in $\mathrm{Pb}$ concentrations probably resulted in higher $\mathrm{Pb} / \mathrm{M}$ ratios for Colle Gnifetti. The differences in $\mathrm{Cr} / \mathrm{Cd}$ and $\mathrm{Zn} / \mathrm{Cu}$ ratios between Alto dell'Ortles and Colle Gnifetti may be explained by different mobilization of these metals along an altitudinal transect, due to a different size distribution of their respective aerosol particles (Allen et al., 2001). In addition, although the mixing of pollutants within the Po Valley is very efficient (Deserti et al., 2006), the presence of hot-spot emissions may cause heterogeneous pollutant deposition over the Alps.

\subsection{Meteorological and atmospheric conditions}

In order to better explain the observed differences in the seasonal deposition of trace species to the Alto dell'Ortles glacier we have investigated the atmospheric pathways from the source regions to the study area. We computed the daily back-trajectories from Alto dell'Ortles glacier (at 3850 m a.s.1.) from 2007 to 2009, using the Hybrid SingleParticle Lagrangian Integrated Trajectory Model (HYSPLIT 4.8), provided by the National Oceanic and Atmospheric Administration (NOAA) which is a tool to simulate air particles 

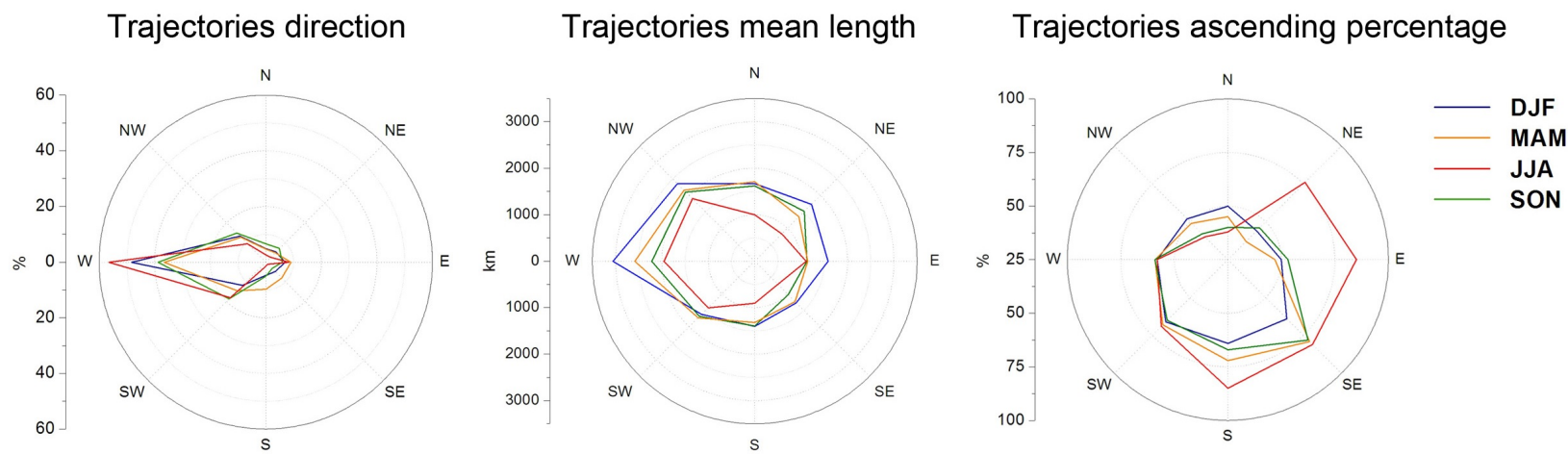

Fig. 5. Summary of seasonal characteristics of air mass back-trajectories, calculated using the NOAA HYSPLIT model, in the three years 2007-2009 time period (DJF: December, January, February; MAM: March, April, May; JJA: June, July, August; SON: September, October, November).

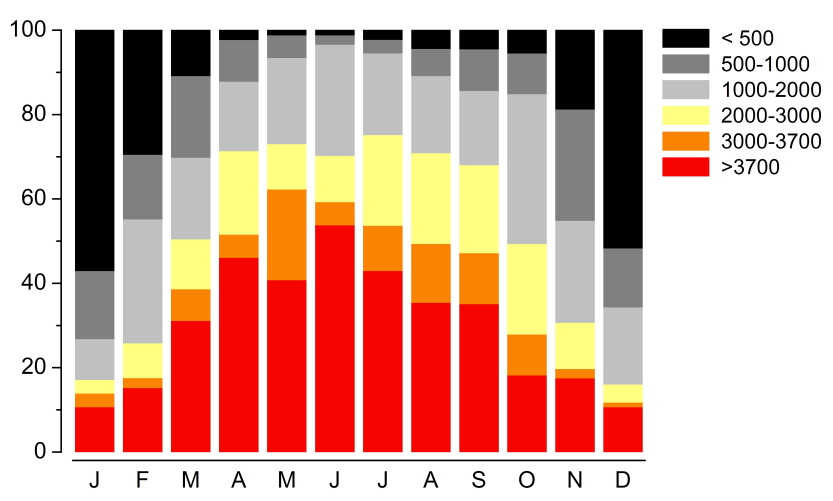

Fig. 6. Percentage distribution of the monthly averaged maximum boundary layer depth (in meters), inferred from the balloon data analysis at the Milano-Linate Airport meteorological station over the 2007-2009 years period.

transport and deposition (Draxler and Rolph, 2010; Draxler, 2003). We used the global dataset archive (GDA) containing 29 meteorological single level variables (at the surface) and 6 upper levels variables (for a total of 23 vertical levels from 1000 to $20 \mathrm{hPa}$ ) to calculate 48 -h back-trajectories. For each day, we performed two model runs at 00:00 and 12:00 UTC. The model results are summarized in Fig. 5. Air masses from western quadrants (from SW to $\mathrm{NW}$ ) represent more than $84 \%$ of the total during summer (JJA), and $63-73 \%$ in the other seasons. Northern trajectories (NW to NE) are larger in autumn (SON), and fewer in winter (DJF), representing $28 \%$ and $14 \%$ of the wind sources, respectively. Southern air masses (SE to SW) characterize the $32 \%$ of spring winds (MAM), $27 \%$ in autumn and about $21 \%$ in winter and summer. The longest $48 \mathrm{~h}$ trajectories originate from the west and cover a mean distance of $2450 \mathrm{~km}$, while the trajectories from the northern, southern and eastern quadrants are shorter $(1710,1310$ and $1220 \mathrm{~km}$, respectively). These trajectories are generally longer in DJF and SON than in MAM and JJA. In DJF the mean trajectories lengths from $\mathrm{W}$ and
SE are 1270 and $3050 \mathrm{~km}$, respectively, while in JJA they are 705 and $1955 \mathrm{~km}$ (about $40 \%$ shorter). The back-trajectories containing a predominant ascending behavior, which are often associated to cyclonic fields, are more frequent in JJA where they comprise $65 \%$ of the total and include $55 \%$ of the trajectories for all the other periods of the year. Ascending air masses originate generally from the south and southeast (64-85\% of the total) but in JJA ascending air mass trajectories from the east represent more than $80 \%$ of total eastern fluxes.

Despite the significant seasonal differences in the origin and behavior of air masses, as inferred from the evaluation of 48-h back-trajectories, these origins hardly explain the magnitude of the large changes in concentrations that are observed in the snow pit chemical profiles. In fact, a fundamental parameter that has to be taken into account to explain the seasonal variation in concentrations is the vertical structure of the troposphere at a regional scale. In winter, the Alto dell'Ortles glacier lies within the free troposphere because the vertical motions are inhibited by low-altitude thermal inversions with very stable atmospheric stratifications (Kappenberger and Kerkmann, 1997). In Fig. 6, we summarize the averaged monthly variations in the maximum boundary layer depth (BLD), at the meteorological station of MilanoLinate Airport ( $\sim 100 \mathrm{~km} \mathrm{SW}$ of Mt. Ortles), obtained by analyzing the daily balloon data over 2007-2009. The BLD was deduced by analyzing the thermal profiles inferred from balloon launches (every day at 00:00 and 12:00 UTC and, in case of particularly unstable meteorological conditions, also at 06:00, 09:00, 15:00, 18:00 and 21:00 UTC), and by identifying the daily maximum altitude of the thermal inversion. The balloon data are available at the University of Wyoming website: http://weather.uwyo.edu/upperair/europe.html. We choose the Milano-Linate station because it is indicative of the tropospheric vertical structure of the Po Valley, the main anthropogenic area which affects the air quality over the Alps (Seibert et al., 1998). The maximum daily boundary layer depth is much higher during summer than winter due 
Milan (Linate Airport, 103 m a.s.I.)

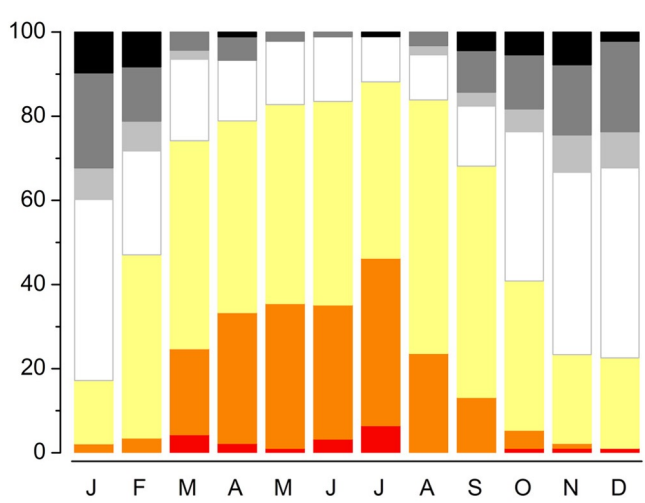

Glacier Alto dell'Ortles (3850 m a.s.I.)

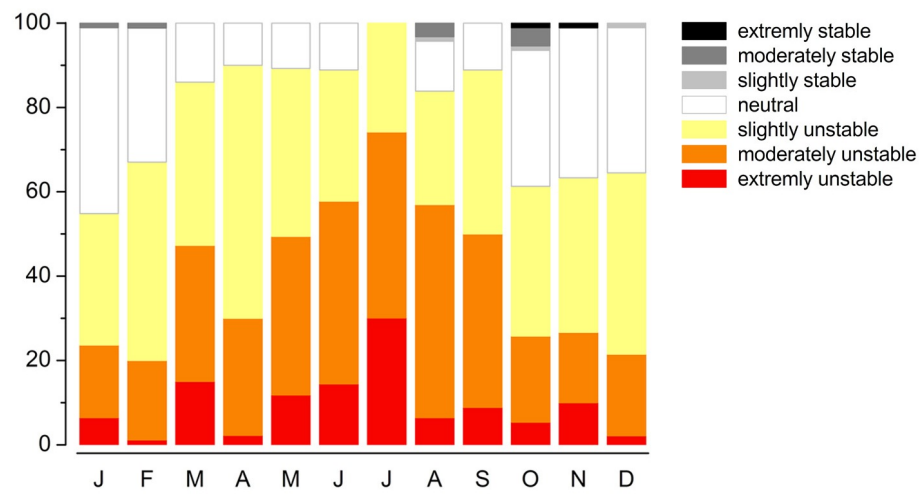

Fig. 7. Monthly percentage distribution of the calculated Pasquill Stability Classes of atmospheric stability calculated at Milano-Linate Airport meteorological station and at the Alto dell' Ortles glacier, over the 2007-2009 years period. The atmospheric state is categorized into six stability classes from the most unstable to the most stable.

to stronger insolation that enables more effective convection. In December and January, only during $15-20 \%$ of the days the boundary layer depth (BLD) is higher than $2000 \mathrm{~m}$. However during $52-57 \%$ of the days the very stable well-mixed boundary layer exists below $500 \mathrm{~m}$. In these conditions, the pollutants emitted at the bottom of the valley cannot be lifted by thermal convection and are confined in a relatively small volume. During the spring, the BLD rises rapidly and, from April to September, the maximum daily BLD is higher than $2000 \mathrm{~m}$ a.s.l. and remains at this elevation for $\sim 70 \%$ of the days. With this rapid rise in the BLD, pollutants are lifted by a synoptically influenced flow, or directly injected to the free troposphere and then transported horizontally by the synoptic flow and then are able to move across Europe.

Figure 7 summarizes the averaged monthly stability situations during the period 2007/2009, according to the Pasquill classification (Pasquill, 1961) at the Milan Linate airport and over the Alto dell'Ortles glacier. This stability is estimated by using the meteorological data (GDA meteorological archive) from the open-source READY system (RealTime Environmental Applications and Display system), provided by the Air Resources Laboratory of NOAA. In Milan about $60-80 \%$ of the days from October to February are characterized by stable or neutral atmospheric conditions, with $17-38 \%$ of days characterized by slightly unstable conditions and only $2-4 \%$ by moderately and extremely unstable conditions. From March to September, unstable meteorological situations dominate, representing $70-80 \%$ of the total. At the Alto dell'Ortles glacier, stable meteorological conditions are rare when compared to Milan. In general we note a higher frequency of moderately and extremely unstable conditions during the entire year with a particular increase from October to February when unstable conditions predominate for about $20-25 \%$ of the total compared with only $2-4 \%$ of the time at Milan. From March to June even slightly stable situations are completely absent while neutral conditions account for only $12-16 \%$ of the total days. In July, moderately and extremely unstable conditions represent more than $74 \%$ while $26 \%$ of the days are slightly unstable.

The pollutants emitted from the heavily industrialized and populated Po Valley during the winter season are thus trapped by the very stable low-altitude boundary layer produced by the strong thermal inversion, which therefore limits transfer to the free troposphere. Low velocity vertical winds are often not sufficient to penetrate the boundary layer and to lift polluted air from the lower to the upper tropospheric levels. For this reason during winter, when the Alto dell'Ortles glacier almost permanently lies above the boundary layer altitude, the glacier is likely uninfluenced by local/regional anthropogenic emissions produced in the southwestern Po Valley. The winter western atmospheric fluxes and depositions to the Alto dell'Ortles glacier are likely more representative of continental air quality background conditions at similar elevations, except during the rare unstable winter meteorological conditions such as Foehn events. The Alpine Foehn, is a rain shadow wind which results from the subsequent adiabatic warming of air which has released most of its moisture on windward slopes.

During the rest of the year, the meteorology is characterized by vertical exchanges between the low level and free troposphere, allowing the mass transfer from local (Val Venosta in the north and Val di Sole in the south) and regional sources (Po Valley) to high elevations. Pollutants from the Po Valley are transferred vertically to the injection layer and then dragged by synoptically influenced flows to the Alpine barrier where they are effectively lifted by upslope winds triggered during the daytime by the solar radiation (Kappenbergher and Kerkmann, 1999). These vertical motions often produce shallow cumulus clouds above the crests and linked small-scale convective precipitation allows wet deposition of transported pollutants and trace species. 


\section{Conclusions}

This work provides an initial insight into the occurrence of numerous trace elements and major ions in fresh snow from Alto dell'Ortles, the highest glacier in the Eastern Alps. The fluxes of $\mathrm{Ba}, \mathrm{Mn}, \mathrm{Fe}$ and $\mathrm{Al}$ are 50-75\% lower with respect to those on Colle Gnifetti during the last decades, providing evidence for relatively low recent crustal dust deposition on Mt. Ortles. The ionic fluxes to Mt. Ortles are similar to those to Colle Gnifetti, Careser and Stubai but much lower than those to $\mathrm{Col}$ du Dome, Fiescherhorngletscher and Grenzgletscher. The PCA applied to the entire dataset provides a clear separation between trace species originated from crustal, (Mg, Ca, Li, Rb, Sr, Ba, Be, Al, Ti, Fe, Ga, Mn, $\mathrm{Co}, \mathrm{U}$ ), anthropogenic (TOC, $\mathrm{NO}_{3}^{-}, \mathrm{SO}_{4}^{2-}, \mathrm{NH}_{4}^{+}, \mathrm{As}, \mathrm{Cd}$, $\mathrm{Sb}, \mathrm{Pb}, \mathrm{Bi}, \mathrm{V}, \mathrm{Ni}, \mathrm{Cu}, \mathrm{Zn})$ and marine sources $\left(\mathrm{Cl}^{-}, \mathrm{Na}^{+}\right)$. In addition, a pronounced seasonality in deposition is apparent. Summer snow appears more affected by anthropogenic and marine contributions while the aerosol flux is dominated by crustal and terrigenous sources during winter. All anthropogenic ions $\left(\mathrm{NH}_{4}^{+}, \mathrm{NO}_{3}^{-}, \mathrm{SO}_{4}^{2-}\right)$ and trace elements $(\mathrm{Cd}$, $\mathrm{Sb}, \mathrm{Zn}, \mathrm{Cu}, \mathrm{Pb}$ ) demonstrate a pronounced seasonal pattern, with low winter concentrations that increase in spring and peak in summer.

The comparison of trace species and elements ratios in local and Po Valley emissions with those in Alto dell'Ortles snow and firn demonstrates that summer deposition on Mt. Ortles is linked with Po Valley emissions. Despite significant climatic differences, especially in the precipitation regimes, a comparison between trace element ratios from Alto dell'Ortles and high-altitude glaciers over the Western Alps indicates similar sources and transport processes, even at seasonal time scales. In general, the large seasonal changes in major and trace element concentrations both in the Western and the Eastern Alps appear homogenously linked to the vertical structure of the troposphere at a regional scale rather than the synoptic weather patterns.

Acknowledgements. This work is a contribution to the Ortles project, a program supported by the Fire protection and civil division of the Autonomous Province of Bolzano (Michela Munari) in collaboration with the Forest division of the Autonomous Province of Bolzano (Paul Profanter, Barbara Folie) and the National Park of Stelvio (Wolfgang Platter). This is the Ortles project publication 2. This is also Byrd Polar Research Center contribution 1412. For the field operations we thank: Volkmar Mair, (Geologic Office of the Autonomous Province of Bolzano), Reinhard Pinggera (Forest Division of the Autonomous Province of Bolzano) Philipp Rastner (EURAC), Karl Krainer (University of Innsbruck), Paul Vallelonga (IDPA-CNR and Niels Bohr Institute, Copenhagen), Matteo Cattadori (Museo Tridentino di Scienze Naturali) and Toni Stocker (Alpine Guides of Solda). We also thank Anselmo Cagnati and Andrea Crepaz (Arabba Avalanche Centre, ARPAV), for the useful comments about the stratigraphic observations. We are also grateful to Ping-Nan Lin (Byrd Polar Research Center, The Ohio State University) for the stable isotopes analyses. Finally, the authors gratefully acknowledge the NOAA Air Resources Laboratory
(ARL) for the provision of the HYSPLIT transport and dispersion model and READY website (http://www.arl.noaa.gov/ready.php) used in this publication.

Edited by: R. Ebinghaus

\section{References}

Allen, A., Nemitz, E., Shi, J., Harrison, R., and Greenwood, J.: Size distribution of trace metals in atmospheric aerosol in the United Kingdom, Atmos. Environ., 35, 4581-4591, 2001.

Barbante, C., Van de Velde, K., Cozzi, G., Capodaglio, G., Cescon, P., Planchon, F., Hong, S., Ferrari, C., and Boutron, C.: PostWorld War II Uranium Changes in Dated Mont Blanc Ice and Snow, Environ. Sci. Technol., 35, 4026-4030, 2001.

Barbante, C., Schwikowski, M., Doring, T., Gaggeler, H. W., Schotterer, U., Tobler, L., Van de Velde, K., Ferrari, C., Cozzi, G., Turetta, A., Rosman, K., Bolshov, M., Capodaglio, G., Cescon, P., and Boutron, C.: Historical Record of European Emissions of Heavy Metals to the Atmosphere Since the 1650s from Alpine Snow/Ice Cores Drilled near Monte Rosa, Environ. Sci. Technol., 38, 4085-4090, 2004.

Barbante, C., Gabrieli, J., Gabrielli, P., Vallelonga, P., Cozzi, G., Turetta, C., Hong, S., Rosman, K., Boutron, C., and Cescon, P.: A historical record of heavy metal pollution in Alpine snow and ice, in: Persistent Pollution - Past, Present, Future, edited by: Quante, M., Ebingaus, R., and Floser, G., Spriger Verlag, Berlin, 2011.

Bolius, D.: Paleo climate recosntruction based on ice cores from the Andes and the Alps, PhD thesis, Universitat Bern, Switzerland, 2006.

Brunetti, M., Maugeri, M., Monti, F., and Nanni, T.: Temperature and precipitation variability in Italy in the last two centuries from homogenized instrumental time series, Int. J. Climatol, 26, 345381, 2006.

Cagnati, A. (Ed.): Strumenti di misura e metodi di osservazione nivometeorologici, AINEVA, Trento (Italy), 2003.

Collaud Coen, M., Weingartner, E., Schaub, D., Hueglin, C., Corrigan, C., Henning, S., Schwikowski, M., and Baltensperger, U. Saharan dust events at the Jungfraujoch: detection by wavelength dependence of the single scattering albedo and first climatology analysis, Atmos. Chem. Phys., 4, 2465-2480, doi:10.5194/acp4-2465-2004, 2004.

Davis, B. A. S., Brewer, S., Stevenson, A. C., and Guiot, J.: The temperature of Europe during the Holocene reconstructed from pollen data, Quaternary Sci. Rev., 22, 1701-1716, 2003.

Deserti, M., Bande, S., Angelino, E., Pession, G., Dalan, F., Minguzzi, E., Stortini, M., Bonafè, G., De Mria, R., Fossati, G., Peroni, E., Costa, M., Liguori, F., and Pillon, S.: Rapporto tecnico sull'applicazione di modellistica al Bacino Padano Adriatico, APAT, Roma (Italy), 2006.

Desio, A. (Ed.): I ghiacciai del Gruppo Ortles-Cevedale, Comitato Glaciologico Italiano, Torino (Italy), 1967.

Doescher, A., Gaggeler, H., Schotterer, U., and Schwikowski, M.: A 130 years deposition record of sulfate, nitrate and chloride from a high-altitude glacier, Water Air Soil Poll., 85, 603-609, 1995.

Draxler, R. R.: Evaluation of an ensemble dispersion model, J. Appl. Meteorol., 42, 308-317, 2003. 
Draxler, R. R. and Rolph, G. D. (Eds.): HYSPLIT (HYbrid Single-Particle Lagrangian Integrated Trajectory) Model access via NOAA ARL READY Website (http://ready.arl.noaa.gov/ HTSPLIT.php), NOAA Air Resources Laboratory, Silver Spring, MD, 2010.

Eichler, A., Schwikowski, M., and Gaggeler, H.: An Alpine icecore record of anthropogenic $\mathrm{HF}$ and $\mathrm{HCl}$ emissions, Geophys. Res. Lett., 27, 3225-3228, 2000.

Eichler, A., Schwikowski, M., and Gaggeler, H.: Meltwaterinduced relocation of chemical species in Alpine firn, Tellus, 53, 192-203, 2001.

Eichler, A., Schwikowski, M., Furger, M., Schotterer, U., and Gäggeler, H. W.: Sources and distribution of trace species in Alpine precipitation inferred from two 60-year ice core paleorecords, Atmos. Chem. Phys. Discuss., 4, 71-108, doi:10.5194/acpd-4-71-2004, 2004.

Fierz, C., Armstrong, R. L., Durand, Y., Etchevers, P., Greene, E., McClung, D. M., Nishimura, K., Satyawali, P. K., and Sokratov, S. A. (Eds.): The International Classification for Seasonal Snow on the Ground, IHP-VII Technical Documents in Hydrology $\mathrm{N}^{\circ} 83$, IACS Contribution $\mathrm{N}^{\circ} 1$, UNESCO-IHP, Paris (France), 2009.

Frei, C. and Schär, C.: A precipitation climatology of the Alps from high-resolution rain-gauge observations, Int. J. Climatol., 18, 873-900, 1998.

Gabrieli, J.: Trace elements and polycyclic aromatic hydrocarbons (PAHs) in snow and ice sampled at Colle gnifetti, Monte Rosa $(4450 \mathrm{~m})$, during the past 10,000 years: environmental and climatic implications, $\mathrm{PhD}$ thesis, University Ca' Foscari of Venice, Italy, 2008.

Gabrieli, J., Decet, F., Luchetta, A., Valt, M., Pastore, P., and Barbante, C.: Occurence of PAHs in seasonal snowpack of Eastern Italian Alps, Environ. Pollut., 158, 3130-3137, 2010.

Gabrieli, J., Vallelonga, P., Cairns, W., Cozzi, G., Spolaor, A., Sigl, M., Schwikowski, M., Boutron, C. F., and Barbante, C.: A new melting system for high resolution trace elements determination in alpine firn and ice cores, to be submitted to J. Environ. Monitor., 2011.

Gabrielli, P., Cozzi, G., Torcini, S., Cescon, P., and Barbante, C.: Trace elements in winter snow of the Dolomites (Italy): A statistical study of natural and anthropogenic contributions, Chemosphere, 72, 1504-1509, 2008.

Gabrielli, P., Carturan, L., Gabrieli, J., Dinale, R., Krainer, K., Helmut, H., Davis, M., Zagarodnov, V., Seppi, R., Barbante, C., Dalla Fontana, G., and Thompson, L. G.: Atmospheric warming threatens the untapped glacial archive of Mt. Ortles, South Tyrol, J. Glaciol., 56, 843-853, 2010.

Hong, S., Lee, K., Hou, S., Hur, S. D., Ren, J., Burn, L. J., Rosman, K. J. R., Barbante, C., and Boutron, C. F.: An 800-Year Record of Atmospheric As, Mo, Sn, and Sb in Central Asia in HighAltitude Ice Cores from Mt. Qomolangma (Everest), Himalayas, Environ. Sci. Technol., 43, 8060-8065, 2009.

Jenk, T. M., Szidat, S., Bolius, D., Sigl, M., Gaggeler, H. W., Wacker, L., Ruff, M., Barbante, C., Boutron, C. F., and Schwikowski, M.: A novel radiocarbon dating technique applied to an ice core from the Alps indicating late Pleistocene ages, J. Geophys. Res., 114, D14305, doi:10.1029/2009JD011860, 2009.
Kappenberger, G. and Kerkmann, J. (Eds.): Il tempo in montagna. Manuale di meteorologia alpina, Zanichelli, Bologna (Italy), 1997.

Kaspari, S., Mayewski, P. A., Handley, M. J., Osterberg, E. C., Kang, S., Hou, S., and Qin, D.: Recent increase in atmospheric concentrations of Bi, U, Cs, Ca and S from a 350-year Mt. Everest ice core record, J. Geophys. Res., 114, D04302.1-D04302.14, doi:10.1029/2008JD011088, 2009.

Kuhn, M., Haslhofer, J., Nickus, U., and Schellander, H.: Seasonal development of ion concentration in a high alpine snow pack, Atmos. Environ., 32, 4041-4051, 1998.

Lavanchy, V. M. H., Gaggeler, H. W., Schotterer, U., Schwikowski, M., and Baltensperger, U.: Historical record of carbonaceous particle concentrations from a European high-alpine glacier (Colle Gnifetti, Switzerland), J. Aerosol Sci., 30, S611-S612, 1999.

Maupetit, F. and Delmas, R. J.: Snow chemistry of high altitude glaciers in the French Alps, Tellus, 46B, 304-324, 1994.

McConnell, J. R., Lamorey, G. W., and Hutterli, M.: A 250-year high-resolution record of $\mathrm{Pb}$ flux and crustal enrichment in central Greenland, Geophys. Res. Lett., 29, 2130-2133, 2002.

Novo, A. and Rossi, G. C.: A four-year record (1990-94) of snow chemistry at two Glacier fields in the Italian Alps (Careser, 3090m; Colle Vincent, 4086m), Atmos. Environ., 32, 40614073, 1998.

Ozeki, T. and Akitaya, E.: Energy balance and formation of sun crust in snow, Ann. Glaciol., 26, 35-38, 1998.

Pacyna, J. M. and Pacyna, E. G.: An assesment of global and regional emissions of trace metals to the atmosphere from anthropogenic sources worldwide, Environ. Rev., 9, 269-298, 2001.

Pasquill, F.: The estimation of the dispersion of windborne material, The Meteorol. Mag., 90, 33-49, 1961.

Planchon, F., Van de Velde, K., Rosman, K. J. R., Wolf, C. F., Ferrari, C., and Boutron, C. F.: One houndred fifty-year record of lead isotopes in Antartic snow from Coats Land, Geochim. Cosmochim. Ac., 67, 693-708, 2003.

Preunkert, S., Wagenbach, D., Legrand, M., and Vincent, C.: Col du Dome (Mt. Blanc massif, French Alps) suitability for ice core studies in relation with past atmospheric chemistry over Europe, Tellus, 52, 993-1012, 1999.

Puxbaum, H. and Tscherwenka, W.: Relationships of major ions in snow fall and rime at Sonnblick observatory (SBO, 3106m) and implications for scavenging processes in mixed clouds, Atmos. Environ., 32, 4011-4020, 1998.

Schotterer, U., Frohlich, K., Gaggeler, H. W., Sandjordj, S., and Stichler, W.: Isotopes records from Mongolian and Alpine ice cores as climate indicators, Climatic Change, 36, 519-530, 1997.

Schmidli, J., Schmutz, C., Frei, C., Wanner, H., and Schär, C.: Mesoscale precipitation variability in the region of the European Alps during the 20th century, International J. Climatol., 22, 1049-1074, 2002.

Schwikowski, M.: Reconstruction of European air pollution from Alpine ice cores, in: Earth Paleoenvironments: records preserved in mid- and low-latitude glaciers, edited by: Cecil, D. L., Green, J. R., and Thompson, L. G., Kluwer Academic Publisher, Dordrecht, Netherlands, 95-119, 2004.

Schwikowski, M., Doscher, A., Gaggeler, H., and Schotterer, U.: Anthropogenic versus natural sources of atmospheric sulphate from an Alpine ice core, Tellus, 51B, 938-951, 1999. 
Schwikowski, M., Barbante, C., Doering, T., Gaeggeler, H. W., Boutron, C., Schotterer, U., Tobler, L., Van de Velde, K., Ferrari, C., Cozzi, G., Rosman, K., and Cescon, P.: Post-17thCentury Changes of European Lead Emissions Recorded in High-Altitude Alpine Snow and Ice, Environ. Sci. Technol., 38, 957-964, 2004.

Shotyk, W., Zheng, J., Krachler, M., and Zdanowicz, C.: Predominance of industrial $\mathrm{Pb}$ in recent snow (1994-2004) and ice (1842-1996) from Devon Island, Arctic Canada, Geophys. Res. Lett., 32, 21814.1-21814.4, 2005.

Seibert, P., Kromp-kolb, H., Kasper, A., Kalina, M., Puxbaum, H., Jost, D. T., Schwikowski, M., and Baltensperger, U.: Transport of polluted boundary layer air from the Po Valley to high-alpine sites, Atmos. Environ., 32, 3953-3965, 1998.

Sigl, M. : Ice core based reconstruction of past climate conditions from Colle Gnifetti, Swiss Alps, PhD thesis, Universitat Bern, Switzerland, 2009.

Simoneit, B. R. T.: Biomass burnings - a review of organic tracers for smoke from incomplete combustion, Appl. Geochem., 17, 129-162, 2002.

Van de Velde, K., Boutron, C., Ferrari, C., Bellomi, T., Barbante, C., Rudnev, S., and Bolshov, M.: Seasonal variations of heavy metals in the 1960s Alpine ice: sources versus meteorological factors, Earth Planet. Sci. Lett., 164, 521-533, 1998.
Van de Velde, K., Ferrari, C., Barbante, C., Moret, I., Bellomi, T., Hong, S., and Boutron, C.: A 200 year record of atmospheric Cobalt, Chromium, Molybdenum and Antimony in high altitude Alpine firn and ice, Environ. Sci. Technol., 33, 3496-3501, 1999.

Van de Velde, K., Barbante C., Cozzi, G., Moret, I., Bellomi, T., Ferrari, C., and Boutron, C.: Changes in the occurrence of Silver, Gold, Platinum, Palladium and Rhodium in Mont Blanc ice and snow since 18th century, Atmos. Environ., 34, 3117-3127, 2000.

Veysseyre, A., Moutard, K., Ferrari, C., Velde, K. V. d., Barbante, C., Cozzi, G., Capodaglio, G., and Boutron, C.: Heavy metals in fresh snow collected at different altitudes in the Chamonix and Maurienne valleys, French Alps: initial results, Atmos. Environ., 35, 415-425, 2001.

Wedepohl, K. H.: The composition of the continental crust, Geochim. Cosmochim. Ac., 59, 1217-1232, 1995.

Weiss, D., Shotyk, W., Appleby, P. G., Kramers, J. D., and Cheburkin, A. K.: Atmospheric Pb Deposition since the Industrial Revolution Recorded by Five Swiss Peat Profiles: Enrichment Factors, Fluxes, Isotopic Composition, and Sources, Environ. Sci. Technol., 33, 1340-1352, 1999. 